\title{
OXIDATIVE STRESS INHIBITS THE PROLIFERATION, INDUCES PREMATURE SENESCENCE AND PROMOTES A CATABOLIC PHENOTYPE IN HUMAN NUCLEUS PULPOSUS INTERVERTEBRAL DISC CELLS
}

\author{
A. Dimozi ${ }^{\S}, \#$, E. Mavrogonatou ${ }^{\S}$, A. Sklirou ${ }^{\S}$ and D. Kletsas* \\ Laboratory of Cell Proliferation and Ageing, Institute of Biosciences and Applications, National Centre for Scientific \\ Research "Demokritos”, 15310 Athens, Greece \\ $\S$ Authors have equally contributed to this work \\ \# This work is devoted to the memory of Anastasia Dimozi
}

\begin{abstract}
Aged and degenerated intervertebral discs are characterised by a significant increase in the number of senescent cells, which may be associated with the deterioration of this tissue due to their catabolic phenotype. On the other hand, carboxymethyl-lysine has been found to be accumulated with ageing in the proteins of the disc, evidencing the existence of oxidative stress in this tissue. Accordingly, here we investigated the effect of oxidative stress on the physiology of human nucleus pulposus cells. Hydrogen peroxide $\left(\mathrm{H}_{2} \mathrm{O}_{2}\right)$ at subcytotoxic concentrations transiently increased the intracellular levels of reactive oxygen species, activated the p38 MAPK, ERKs, JNKs and Akt signalling pathways and induced the nuclear translocation of NF- $\mathrm{KB}$ and Nrf2. It also provoked DNA damage and triggered a DNA repair response by activating the ATM-Chk2-p53-p2 $1^{\mathrm{WAF} 1}$-pRb pathway, ultimately resulting in a G1 cell cycle delay and the decrease of cells' proliferation. Prolonged exposure to $\mathrm{H}_{2} \mathrm{O}_{2}$ led to premature cellular senescence, as characterised by the inhibition of proliferation, the enhanced senescence-associated $\beta$ galactosidase staining and the over-expression of known molecular markers, without though a significant decrease in the chromosome telomere length. $\mathrm{H}_{2} \mathrm{O}_{2}$-senescent cells were found to possess a catabolic phenotype, mainly characterised by the up-regulation of extracellular matrixdegrading enzymes (MMP-1, -2, -9 and ADAMTS-5) and the down-regulation of their inhibitors (TIMPs), as well as of several proteoglycans, including aggrecan, the major component of the nucleus pulposus. The senescent phenotype could be reversed by $\mathrm{N}$-acetyl-L-cysteine, supporting the use of antioxidants for the improvement of disc physiology and the deceleration of disc degeneration.
\end{abstract}

Keywords: oxidative stress, $\mathrm{H}_{2} \mathrm{O}_{2}$, intervertebral disc nucleus pulposus cells, MAPKs, Akt, Nrf2, NF- $\kappa$ B, ROS, ATM, senescence.

\footnotetext{
*Address for correspondence:

Dr. Dimitris Kletsas

Laboratory of Cell Proliferation and Ageing

Institute of Biosciences and Applications

National Centre for Scientific Research "Demokritos"

15310 Athens, Greece

Telephone number: + 302106503565

Fax number: + 302106511767

E-mail: dkletsas@bio.demokritos.gr
}

\section{Introduction}

Low back pain affects the majority of the population worldwide. The high prevalence of the disease leads to a great financial burden imposed to the health care system for prevention and treatment, while the indirect costs due to absence from work or reduced productivity are also considerable (Katz, 2006). Given its socioeconomic impact, it is of importance to understand the causing factors of this spinal disorder. Even though its aetiology is not yet fully elucidated, it has often been associated with intervertebral disc degeneration (Luoma et al., 2000; Urban and Roberts, 2003).

Intervertebral discs lie between vertebrae and mainly consist of extracellular matrix (ECM), in which a low number of cells are embedded. Two types of intervertebral disc cells are distributed in the two distinct regions of the tissue, i.e. fibroblast-like cells in the outer filamentous annulus fibrosus and chondrocyte-like cells in the inner gel-like nucleus pulposus. The intervertebral disc is characterised by low cellularity due to the prevailing stressful environmental conditions that strictly hold down cell population in a milieu where the provision of nutrients is restricted. However, despite their low numbers, cells are very important for the preservation of a dynamic equilibrium between synthesis and degradation of the disc's ECM, a fundamental characteristic of a healthy tissue. Disturbance of this equilibrium caused by the combination of decreased biosynthesis of ECM structural components and increased degrading enzymatic activity is typical for disc degeneration (Le Maitre et al., 2004; Le Maitre et al., 2006; Le Maitre et al., 2007b; Roberts et al., 2006b). Recently, the presence of a high number of senescent cells has been shown in the intervertebral disc (Freemont, 2009; Gruber et al., 2007; Le Maitre et al., 2007a; Roberts et al., 2006a). Nevertheless, the stimuli leading to this senescent phenotype have not yet been fully elucidated (Kletsas, 2009).

It has been reported that reactive oxygen species (ROS) are produced in the form of hydrogen peroxide $\left(\mathrm{H}_{2} \mathrm{O}_{2}\right)$ in nucleus pulposus cells in vivo (Kim et al., 2009). In addition, advanced glycation end products (AGEs), such as the carboxymethyl-lysine (CML) formed by the oxidation-derived carboxymethyl modification of lysine (Nerlich et al., 1997) are known to accumulate in proteins of the intervertebral disc (Sivan et al., 2006; Vo et al., 2013) and their concentration has been shown to raise with advancing age and/or disc degeneration, especially in the nucleus pulposus (Nerlich et al., 2007). On the other hand, increased levels of ROS have been incriminated with the 
induction of premature cellular senescence in many cell types (Lu and Finkel, 2008; Passos and von Zglinicki, 2006; Toussaint et al., 2000).

Even though oxidative stress can regulate proliferation and provoke premature senescence in various cell types, little is known about the role of this type of stress in intervertebral disc cells. For that reason and given the documented presence of $\mathrm{H}_{2} \mathrm{O}_{2}$ in the disc in vivo, and especially in the nucleus pulposus, here we assessed the effect of this oxidative agent on the proliferation and induction of senescence in human nucleus pulposus intervertebral disc cells in vitro. Additionally, the gene expression profile and the putative catabolic phenotype of the resulting after $\mathrm{H}_{2} \mathrm{O}_{2}$ treatment senescent cells were examined.

\section{Materials and Methods}

\section{Isolation of human nucleus pulposus intervertebral} disc cells and cell culture conditions

Human intervertebral disc cells used in this study were from a pre-existing cell bank of our laboratory established by Pratsinis et al. (Pratsinis et al., 2012). All cells were isolated from tissues acquired from consenting patients subjected to an orthopaedic operation. In brief, the nucleus pulposus was separated from the annulus fibrosus during surgery based on the different morphology of the two regions. After chopping under aseptic conditions and collagenase digestion, the released cells were recovered by centrifugation. The characterisation of nucleus pulposus and annulus fibrosus cells was performed based on the specific aggrecan and collagen II (markers for nucleus pulposus cells) and collagen I (marker for annulus fibrosus cells) gene expression, respectively (data not shown). Cultures were maintained in DMEM containing antibiotics
(100 U/mL penicillin and $100 \mu \mathrm{g} / \mathrm{mL}$ streptomycin, Biochrom AG, Berlin, Germany) and $20 \%$ (v/v) FBS (Gibco BRL, Invitrogen, Paisley, UK) and subcultured when confluent with a trypsin/citrate $(0.25 \% / 0.30 \%$, w/v) solution.

\section{Estimation of reactive oxygen species' production}

The 2',7'-dichlorfluorescein-diacetate (DCFH-DA) assay was used for the measurement of ROS production (Mavrogonatou et al., 2010) in nucleus pulposus cells treated with $\mathrm{H}_{2} \mathrm{O}_{2}$. Cells were plated in quadruplicates in 96-well plates with DMEM containing $20 \%$ (v/v) FBS until $\sim 90 \%$ confluence. $\mathrm{H}_{2} \mathrm{O}_{2}$ (Sigma, St. Louis, MO, USA) was added in concentrations from 0 to $1 \mathrm{mM}$ along with $10 \mu \mathrm{M}$ of DCFH-DA (Sigma). The kinetics of ROS production up to $72 \mathrm{~h}$ (as a \% ratio of the untreated control) was monitored using the Infinite 200 Tecan microtiter-plate photometer (Tecan Trading AG, Switzerland).

\section{Estimation of cell viability, proliferation and cell cycle progression}

The effect of different concentrations of $\mathrm{H}_{2} \mathrm{O}_{2}(0-2 \mathrm{mM})$ on the viability of human nucleus pulposus cells was investigated using the MTT assay, as previously described (Mavrogonatou et al., 2014). Briefly, cells were plated in quadruplicates in DMEM containing $20 \%(\mathrm{v} / \mathrm{v}) \mathrm{FBS}$ in 96-well plates until $\sim 90 \%$ confluence before the addition of $\mathrm{H}_{2} \mathrm{O}_{2}$ for $72 \mathrm{~h}$. Cell viability was estimated using the ratio of $\mathrm{OD}_{550}$ of $\mathrm{H}_{2} \mathrm{O}_{2}$-treated cells to the untreated controls.

The proliferation of nucleus pulposus cells exposed to $\mathrm{H}_{2} \mathrm{O}_{2}$ treatment was assessed with the DNA synthesis assay, as reported earlier (Mavrogonatou and Kletsas, 2009). In detail, cells were grown in 48-well plates in DMEM supplemented with $20 \%$ (v/v) FBS until 80$90 \%$ confluence and $0-2 \mathrm{mM} \mathrm{H}_{2} \mathrm{O}_{2}$ along with $0.1 \mu \mathrm{Ci}$ / $\mathrm{mL}\left[\right.$ methyl- $\left.{ }^{3} \mathrm{H}\right]$-thymidine (Amersham Biosciences,

Table 1. Real-time PCR primers

\begin{tabular}{|c|c|c|}
\hline Target gene & Forward Primer & Reverse Primer \\
\hline $\mathrm{p} 16^{\mathrm{INK} 4}$ & TAGTTACGGTCGGAGGCCGAT & GCACGGGTCGGGTGAGAG \\
\hline $\mathrm{p} 21^{\mathrm{WAF} 1}$ & CTGGAGACTCTCAGGGTCGAA & CCAGGACTGCAGGGTTCCT \\
\hline Catalase & CCTTTCTGTTGAAGATGCGGCG & GGCGGTGAGTGTCAGGATAG \\
\hline SOD & TGCAGTCTGAAGAGCTATCTC & TGAACGTCACCGAGGAGAAGT \\
\hline COX2 & CCTGTGCCTGATGATTGC & CTGATGCGTGAAGTGCTG \\
\hline ADAMTS-4 & AGAGACAAAGATCCAGGAAAGG & GGCTGAGGACCGTAAAGG \\
\hline ADAMTS-5 & TGTCCTGCCAGCGGATGT & ACGGAATTACTGTACGGCCTACA \\
\hline MMP-1 & CCTTCTACCCGGAAGTTGAG & TCCGTGTAGCACATTCTGTC \\
\hline MMP-2 & AAGAACCAGATCACATACAGGATCA & GTATCCATCGCCATGCTCC \\
\hline MMP-9 & GCACGACGTCTTCCAGTACC & TCAACTCACTCCGGGAACTC \\
\hline MMP-13 & TTGAGCTGGACTCATTGTCG & GGAGCCTCTCAGTCATGGAG \\
\hline TIMP-1 & AAGGCTCTGAAAAGGGCTTC & GAAAGATGGGAGTCGGAACA \\
\hline TIMP-2 & CGACTGGTCCAGCTCTGAC & ACCCACAACCATGTCTAAAAGG \\
\hline TIMP-3 & GCAGATAGACTCAAGGTGTGTGAAA & TCCCTCACTCTTACATGCAGACA \\
\hline ACAN & AGAAGAGAGCCAAACAGC & TTGTGGTTGCCTCTGAAT \\
\hline Biglycan & TCTGTCACACCCACCTACAGC & AGGGGAGATCTCTTTGGGCAC \\
\hline Decorin & CCTGATGACCGCGACTTCGAG & TTTGGCACTTTGTCCAGACCC \\
\hline Versican & ACGGGATTGAAGACACACAAG & AGCCTCAAAATTCAGTGTGTA \\
\hline GAPDH & GAGTCCACTGGCGTCTTC & GCATTGCTGATGATCTTGAGG \\
\hline
\end{tabular}


Buckinghamshire, UK) were added for $24 \mathrm{~h}$. After fixation of the cells and DNA solubilisation, tritiated thymidine incorporation into DNA was estimated by scintillation counting.

Cell cycle analysis was performed in cells fixed with $50 \%(\mathrm{v} / \mathrm{v})$ ethanol after staining with propidium iodide (Sigma), as previously described (Mavrogonatou and Kletsas, 2009). A FACSCalibur flow cytometer (Becton Dickinson, San Jose, CA, USA) was used for the experiments, while the analysis was made with Cell Quest (Becton Dickinson) and Modfit (Verity Software House, Topsham, ME, USA) software.

\section{Western blot analysis}

Protein samples for SDS electrophoresis were collected as reported before in a Laemmli sample buffer containing protease and phosphatase inhibitors (Sigma) (Mavrogonatou and Kletsas, 2009). Western blot analysis was performed using the following antibodies: anti-PARP, anti-phospho-p38 (Thr180/Tyr182), anti-p38, antiphospho-SAPK/JNK (Thr183/Tyr185), anti-SAPK/JNK, anti-phospho-Akt (Ser473), anti-Akt, anti-phospho-Chk2 (Thr68), anti-phopsho-p53 (Ser15) (all purchased from Cell Signalling Technology, Hertfordshire, UK), antiphospho-ERK1/2 (Thr202/Tyr204), panERK, anti-p21 WAF1 (all supplied by BD Transduction Laboratories, Bedford, MA, USA), anti-phospho-ATM (Ser1981), anti-p53 (both supplied by Santa Cruz Biotechnology, Santa Cruz, CA, USA), anti-ATM (Merck Millipore, Billerica, MA, USA), anti-p $16^{\mathrm{INK} 4 \mathrm{a}}$ and anti-pRb (both purchased from BD Pharmingen, San Diego, CA, USA). Anti- $\alpha$-tubulin, as well as the secondary horseradish peroxidase-conjugated antibodies were obtained from Sigma. All primary antibodies were used in a 1:1000 dilution, except for anti-p16 $6^{\text {INK4a }}(1: 400)$ and anti-pRb $(1: 250)$. The enhanced chemiluminescence (ECL) reagent used for visualisation of the results was from Amersham Biosciences.

\section{Immunofluorescence}

For the immunofluorescence experiments assessing the phosphorylation of H2A.X on Ser139 and the localisation of the $\mathrm{p} 65$ subunit of NF- $\mathrm{KB}$ and of Nrf2, cells were grown on glass coverslips before treatment. Fixation and labelling were performed as described previously (Mavrogonatou and Kletsas, 2012) using antibodies against phosphoH2A.X (Ser139) (Upstate Biotechnology, Lake Placid, NY, USA), the p65 subunit of NF- $\kappa \mathrm{B}$ and Nrf2 and a FITC-conjugated IgG (all from Santa Cruz Biotechnology). Counter-staining was performed with $2 \mu \mathrm{g} / \mathrm{mL} \mathrm{4}$, 6-diamidino-2-phenylindole (DAPI) dihydrochloride (Sigma).

The proliferative potential of cells was estimated after dual labelling with 5-bromo-2'-deoxyuridine (BrdU) and DAPI, as previously reported (Pratsinis and Kletsas, 2007) with slight modifications. In brief, cells were permeabilised with $0.2 \%$ Triton X-100 in PBS after fixation, incubated with $2 \mathrm{~N} \mathrm{HCl}$, labelled with an anti-BrdU-FITC antibody (Roche Applied Science, Mannheim, Germany) for $16 \mathrm{~h}$ and counter-stained with $2 \mu \mathrm{g} / \mathrm{mL}$ DAPI.

In all cases, labelled cells were visualised using a Zeiss AxioPlan 2 microscope (Carl Zeiss, Jena, Germany). For the quantification of BrdU incorporation, approximately a total of 200 cells from at least two different fields were counted.

\section{Evaluation of $\mathrm{H}_{2} \mathrm{O}_{2}$-induced premature senescence}

For the evaluation of $\mathrm{H}_{2} \mathrm{O}_{2}$-induced premature senescence in human nucleus pulposus intervertebral disc cells, several protocols were tested (data not shown). The protocol that was ultimately applied included four consecutive exposures of confluent cultures to $500 \mu \mathrm{M} \mathrm{H}_{2} \mathrm{O}_{2}$ in DMEM supplemented with $10 \%(\mathrm{v} / \mathrm{v}) \mathrm{FBS}$, with a $3 \mathrm{~d}$ interval between two sequential exposures to $\mathrm{H}_{2} \mathrm{O}_{2}$. The final plating of the cells for the assessment of markers of senescence was made three days after the last exposure to $\mathrm{H}_{2} \mathrm{O}_{2}$. Whenever necessary, cells were pre-incubated with $2 \mathrm{mM}$ N-acetyl-L-cysteine (NAC, Sigma) for $16 \mathrm{~h}$ before medium change to DMEM supplemented with $10 \%(\mathrm{v} / \mathrm{v})$ FBS containing $\mathrm{H}_{2} \mathrm{O}_{2}$ or DMEM supplemented with $10 \%$ (v/v) FBS containing $\mathrm{H}_{2} \mathrm{O}_{2}$ and NAC.

\section{Senescence-associated $\beta$-galactosidase (SA- $\beta$-gal) staining}

SA- $\beta$-gal staining was performed as reported before (Konstantonis et al., 2013). Briefly, cells were grown on glass coverslips and fixed with $3 \%(\mathrm{v} / \mathrm{v})$ formaldehyde in PBS. Fixed cultures were incubated with the SA- $\beta$-gal staining solution $(40 \mathrm{mM}$ citric acid /sodium phosphate pH 6.0, $150 \mathrm{mM} \mathrm{NaCl}$ and $2 \mathrm{mM} \mathrm{MgCl}_{2}$ containing $5 \mathrm{mM}$ potassium ferricyanide, $5 \mathrm{mM}$ potassium ferrocyanide and $1 \mathrm{mg} / \mathrm{mL} \mathrm{X-Gal)}$ for $24 \mathrm{~h}$ at $37^{\circ} \mathrm{C}$. Samples were observed under a Zeiss Axioplan 2 phase contrast microscope.

\section{Telomere length assay}

The measurement of the cells' telomere length was performed using the TeloTAGGG telomere length assay kit (Roche Applied Science) according to the manufacturer's instructions. In brief, $2 \mu \mathrm{g}$ of genomic DNA extracted with the NucleoSpin Tissue XS kit (Macherey-Nagel, Düren, Germany) was digested with Hinfl and RsaI and separated by agarose gel electrophoresis. Capillary southern transfer of the digested DNA to the positively charged nylon membrane Porablot NY plus (Macherey-Nagel) was done with $20 \times$ SSC buffer, while transferred DNA was fixed by baking at $120^{\circ} \mathrm{C}$. The membrane was hybridised with the telomere-specific digoxigenin (DIG)-labelled hybridisation probe and then incubated with an anti-DIG antibody. The generated luminescence signal after incubation with the substrate solution was captured by exposure of the membrane to an X-ray film. Densitometric analysis of the scanned X-ray film after overlaying each sample lane with a grid and subtracting the background was performed with the ImageJ software (Wayne Rasband, National Institutes of Health, Bethesda, MD). The mean terminal restriction fragments (TRF) length has been calculated using the formula:

$$
\text { meanTRF }=\frac{\Sigma(O D \mathrm{i})}{\Sigma\left(\frac{O D \mathrm{i}}{L \mathrm{i}}\right)}
$$

where ODi is the chemiluminescent signal and $\mathrm{Li}$ is the length of the TRF at position i (Harley et al., 1990). 


\section{Real-time PCR analysis}

RNA extraction was done using the Macherey-Nagel NucleoSpin RNA kit following the manufacturer's instructions including an on-column DNase treatment step to remove any residual DNA. First-strand cDNA synthesis and real-time PCR were performed using the PrimeScript RT Reagent Kit (Takara, Tokyo, Japan) and the KAPA SYBR universal fast master mix (KAPA Biosystems, Woburn, MA), respectively as reported earlier (Mavrogonatou et al., 2014). Primers used are listed in Table 1. Relative mRNA expression was calculated using the $2^{-\Delta \Delta \mathrm{Ct}}$ method (Livak and Schmittgen, 2001). Mean Ct values of genes under investigation were normalised to that of glyceraldehyde-3-phosphate dehydrogenase (GAPDH) that served as the reference gene.

\section{Statistical analysis}

Experiments were conducted at least three times. Similar results were obtained in all assays using cells deriving from different donors. Data were tested for normality before the assessment of statistical significant differences using the parametric Student's $t$ test or the non-parametric Mann-Whitney test with Statgraphics Centurion software (Manugistics Inc., Dallas, USA). Values presented are the means \pm standard deviations. Differences were considered statistically significant when $p<0.05$.

\section{Results}

Effect of $\mathrm{H}_{2} \mathrm{O}_{2}$ on the intracellular ROS production, viability and proliferation of human nucleus pulposus cells

In order to evaluate the extent of oxidative stress provoked by $\mathrm{H}_{2} \mathrm{O}_{2}$ in human nucleus pulposus cells, we assessed the differences in the intracellular ROS levels after treatment with several $\mathrm{H}_{2} \mathrm{O}_{2}$ concentrations using the DCFH-DA assay. Even the lowest concentration of $\mathrm{H}_{2} \mathrm{O}_{2}$ used $(0.05 \mathrm{mM})$ led to a rapid significant increase in the production of ROS, while the concentration of $1 \mathrm{mM}$ resulted in a $>3,500$-fold increase of the intracellular ROS levels (Fig. 1). In all cases, $\mathrm{H}_{2} \mathrm{O}_{2}$-induced ROS production considerably increased at $\sim 30 \mathrm{~min}$ of treatment and decreased to a great extent after $48-72 \mathrm{~h} . \mathrm{H}_{2} \mathrm{O}_{2}$ slightly affected cell viability in concentrations up to $0.8 \mathrm{mM}$ (no more than $20 \%$ cell death in comparison to the untreated control) and only at concentrations $\geq 1 \mathrm{mM}$ it abruptly decreased the viability of nucleus pulposus cells to $\sim 10 \%$ compared to the untreated control (Fig. 2A). $\mathrm{H}_{2} \mathrm{O}_{2}$ mediated cell death was due to apoptosis, as estimated by the formation of typical apoptotic bodies, as well as by the cleavage of poly (ADP-ribose) polymerase (PARP), a renowned marker for apoptosis (Fig. 2B). Finally, $\mathrm{H}_{2} \mathrm{O}_{2}$ was also found to drastically inhibit cell proliferation, as estimated by tritiated thymidine incorporation (Fig. 2C). Interestingly, although the $\mathrm{H}_{2} \mathrm{O}_{2} \mathrm{LD}_{50}$ was found to be very near $1 \mathrm{mM}$ for nucleus pulposus cells, the respective $\mathrm{IC}_{50}$ for cell proliferation proved to be much lower (between 125 and $250 \mu \mathrm{M}$ ). Based on these results, the selected concentration of $\mathrm{H}_{2} \mathrm{O}_{2}$ for the rest of our experiments was

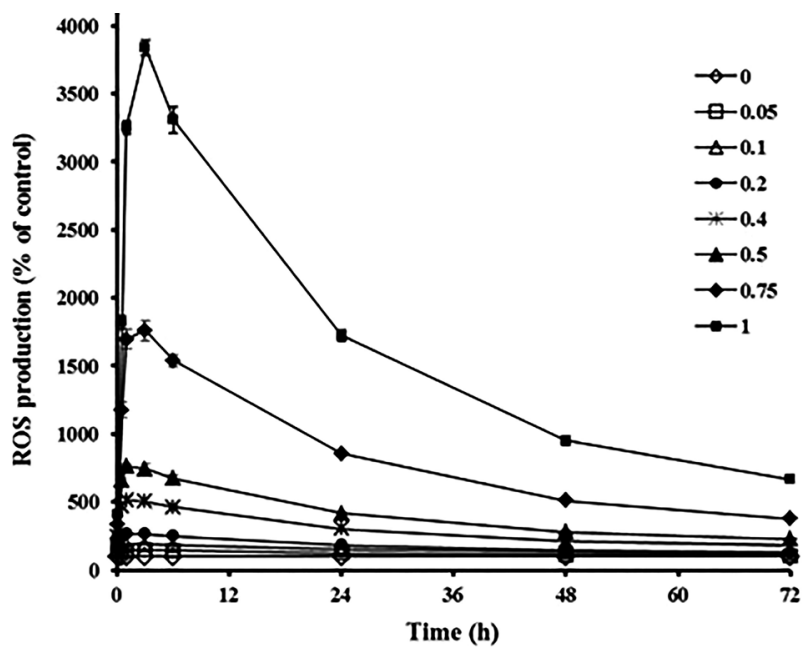

Fig. 1. Estimation of intracellular ROS levels in $\mathrm{H}_{2} \mathrm{O}_{2}$-treated human nucleus pulposus intervertebral disc cells. Cells were plated in a 96-well plate until $\sim 90 \%$ confluence. $\mathrm{H}_{2} \mathrm{O}_{2}$ was added in the designated concentrations along with DCFH-DA $(10 \mu \mathrm{M})$ and measurements were recorded at several time points up to $72 \mathrm{~h}$. Intracellular ROS levels were calculated by dividing the values of treated with $\mathrm{H}_{2} \mathrm{O}_{2}$ cells to those of untreated cells and are presented as a \% ratio of the control. Results are expressed as mean values \pm standard deviations. A representative experiment out of three similar ones performed in quadruplicates is presented here.

$500 \mu \mathrm{M}$, the highest $\mathrm{H}_{2} \mathrm{O}_{2}$ concentration with practically no cytotoxic effect after an exposure of the cells for $72 \mathrm{~h}$.

\section{Mode of action of $\mathrm{H}_{2} \mathrm{O}_{2}$-induced oxidative stress in nucleus pulposus cells}

We then attempted to explore the mechanisms underlying $\mathrm{H}_{2} \mathrm{O}_{2}$ action in our cell model. For that reason, we first assessed the phosphorylation status of the three members of the MAPK superfamily (p38 MAPK, ERKs and JNKs), as well as of Akt, which are all associated with cellular responses to stress and the regulation of cell proliferation and viability. All MAPKs and Akt were found to be rapidly and transiently phosphorylated by $\mathrm{H}_{2} \mathrm{O}_{2}$ (Fig. 3).

In addition, we investigated the putative genotoxic effect of oxidative stress on intervertebral disc cells by assessing the formation of phosphorylated H2A.X foci in the nuclei of the cells after treatment with $\mathrm{H}_{2} \mathrm{O}_{2}$. Indeed, exposure to $500 \mu \mathrm{M} \mathrm{H}_{2} \mathrm{O}_{2}$ resulted in the phosphorylation of H2A.X on Ser139 and the subsequent accumulation of the histone in the sites of DNA damage (Fig. 4A). The presence of H2A.X foci was obvious from $30 \mathrm{~min}$ to $24 \mathrm{~h}$ post-treatment. Nucleus pulposus cells responded towards the genotoxic outcomes of $\mathrm{H}_{2} \mathrm{O}_{2}$ by inducing a DNA repair mechanism, including the activation of ataxia telangiectasia mutated (ATM) kinase, which in turn led to the phosphorylation of Chk2 and p53 (Fig. 4B). In accordance to the observed reduction of proliferation mentioned above, the entire p53-p2 $1^{\mathrm{WAF} 1}-\mathrm{pRb}$ axis was found to be activated in nucleus pulposus cells by $\mathrm{H}_{2} \mathrm{O}_{2}$ 
Fig. 2. Effect of $\mathrm{H}_{2} \mathrm{O}_{2}$ on the viability and proliferation of human nucleus pulposus cells. (A) Cells were grown in DMEM supplemented with $20 \%(\mathrm{v} / \mathrm{v})$ FBS and were exposed to several $\mathrm{H}_{2} \mathrm{O}_{2}$ concentrations (0-2 mM) for $72 \mathrm{~h}$. Then MTT was added, cells were solubilised and optical density was measured at $550 \mathrm{~nm}$. (B) Cells were exposed to $1 \mathrm{mM} \mathrm{H}_{2} \mathrm{O}_{2}$ for 72 or 12-72 h before fixation and DAPI labelling or protein extraction and western blot analysis, respectively. In the first case, samples were visualised under a fluorescence microscope, while in the second case samples were analysed using an antibody for PARP. (C) Cells were plated in DMEM supplemented with $20 \%$ (v/v) FBS before the addition of $0-2 \mathrm{mM} \mathrm{H}_{2} \mathrm{O}_{2}$ along with $0.1 \mu \mathrm{Ci} / \mathrm{mL}\left[\right.$ methyl- $\left.{ }^{3} \mathrm{H}\right]-$ thymidine for $24 \mathrm{~h}$. After fixation of the cells and DNA solubilisation, tritiated thymidine incorporation into DNA was estimated by scintillation counting. In (A) and (C) mean values \pm standard deviations from three experiments are presented, while in (B) representative pictures are depicted. Statistically significant differences in comparison to the control (Student's $t$-test, $p<0.05$ ) are shown by asterisks.
A.

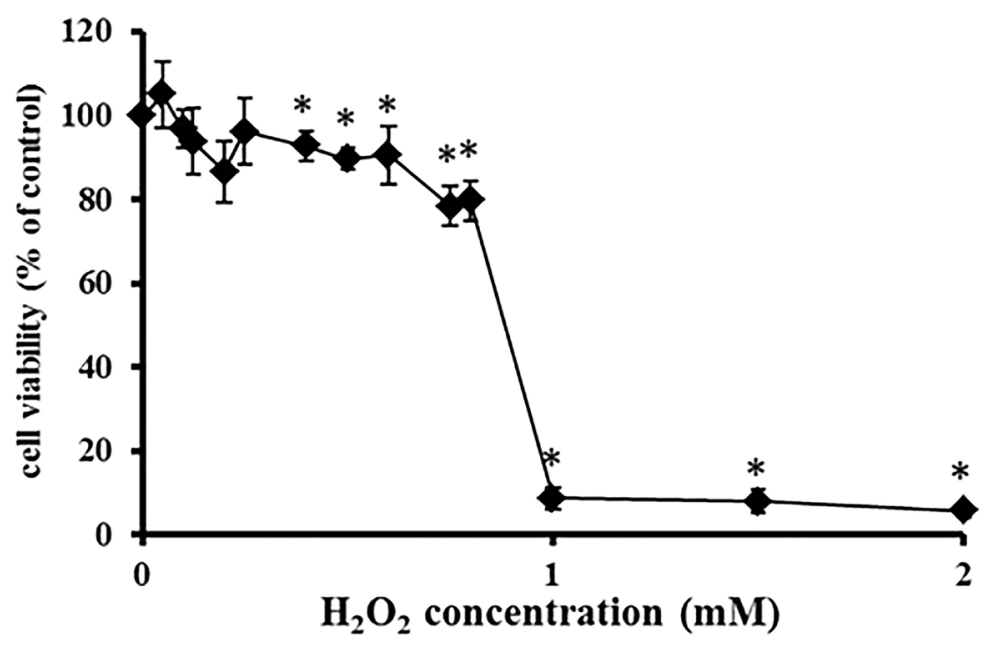

B.

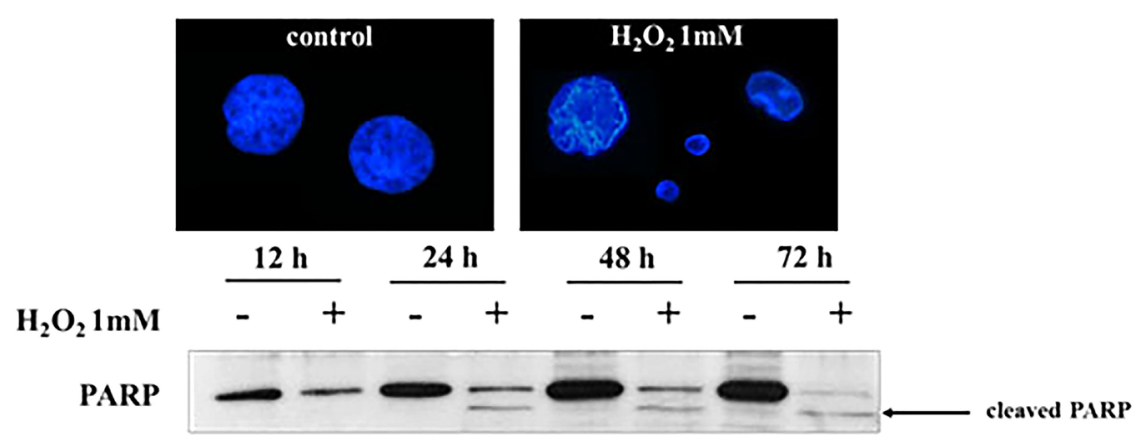

C.

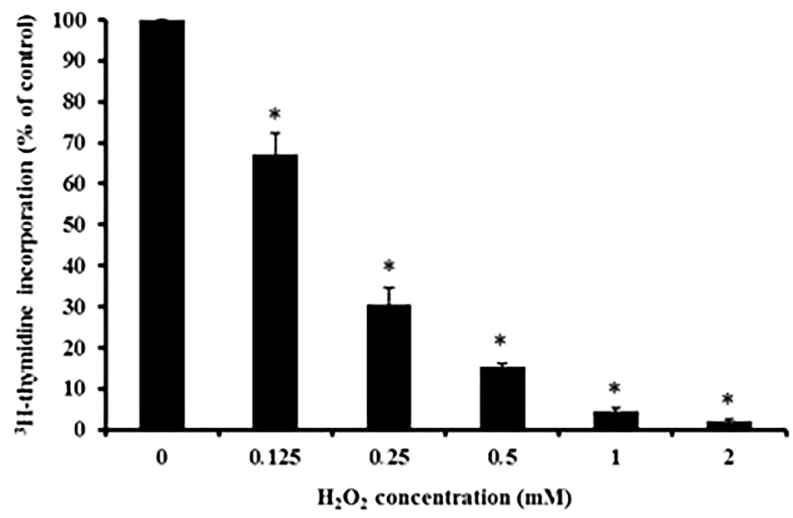

(Fig. 4B), leading to a cell cycle arrest at the G0/G1 phase, accompanied by a decrease in the percentage of the cells accumulating at the G2/M phase (Fig. 4C).

Finally, we examined the subcellular localisation of the transcription factors $\mathrm{NF}-\kappa \mathrm{B}$ and $\mathrm{Nrf} 2$ in nucleus pulposus cells exposed to $500 \mu \mathrm{M} \mathrm{H} \mathrm{H}_{2}$. We observed a nuclear translocation of both NF- $\mathrm{KB}$ p 65 subunit and $\mathrm{Nrf} 2$ in $\mathrm{H}_{2} \mathrm{O}_{2}$ treated cells within $2 \mathrm{~h}$ of exposure (Fig. 5), indicating the activation of these transcription factors as a response to oxidative stress.

Long-term exposure to $\mathrm{H}_{2} \mathrm{O}_{2}$ induces premature senescence in human nucleus pulposus cells

We then followed by investigating the long-term effect of $\mathrm{H}_{2} \mathrm{O}_{2}$ on nucleus pulposus cells. We measured $\mathrm{BrdU}$ incorporation, which indicates the percentage of the putatively proliferating cells in a given population, as well as the SA- $\beta$-gal staining, a classical marker of senescence. We observed a dose-dependent relationship of both parameters with the number of exposures to $\mathrm{H}_{2} \mathrm{O}_{2}$ and a terminally senescent phenotype of the cells after the application of four consecutive exposures to $500 \mu \mathrm{M}$ of $\mathrm{H}_{2} \mathrm{O}_{2}$ (Table 2 and Fig. 6). These senescent cells exhibited a $2 \pm 1 \%$ BrdU incorporation and a $80 \pm 3 \%$ positive SA- $\beta$-gal staining in comparison to the untreated control (in which the respective percentages were $67 \pm 3 \%$ and $15 \pm 3 \%$, respectively) (Fig. 6A). It is worth mentioning that sequential exposures of human nucleus pulposus cells to low $\mathrm{H}_{2} \mathrm{O}_{2}$ concentrations $(1-100 \mu \mathrm{M})$ also resulted in a dose-dependent but more modest reduction of BrdU 
Fig. 3. Phosphorylation of MAPKs and Akt in $\mathrm{H}_{2} \mathrm{O}_{2}$ treated human nucleus pulposus intervertebral disc cells. Cells were grown in 60-mm dishes in DMEM supplemented with $20 \%$ (v/v) FBS until $90 \%$ confluence before the addition of $500 \mu \mathrm{M} \mathrm{H}_{2} \mathrm{O}_{2}$ for the specified time periods. Western blot analysis was performed for the phosphorylated forms of 38 MAPK, ERKs, JNKs and Akt (Ser473). Blots for the nonphosphorylated forms of the kinases are presented to verify equal loading. Four experiments were conducted and representative blots are shown.
$\mathrm{H}_{2} \mathrm{O}_{2}(500 \mu \mathrm{M})$

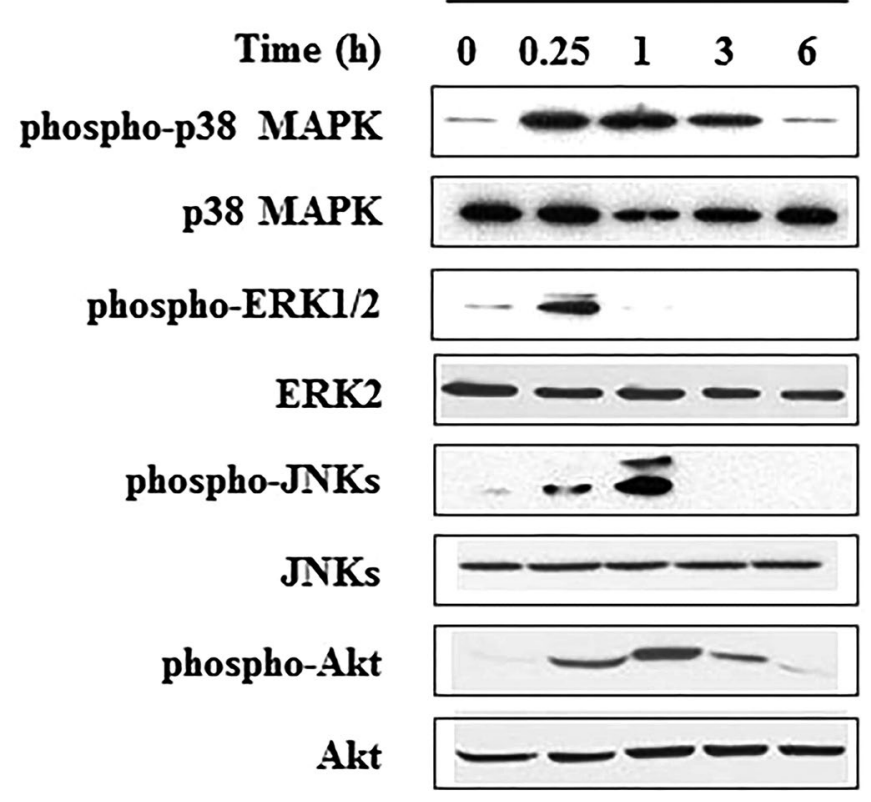

Table 2. Effect of serial exposures to $\mathrm{H}_{2} \mathrm{O}_{2}$ on the induction of senescence in human nucleus pulposus intervertebral disc cells

\begin{tabular}{|c|c|c|}
\hline Number of exposures to $\mathbf{H}_{2} \mathbf{O}_{2}$ & BrdU incorporation (\%) & SA- $\beta$-gal-positive cells (\%) \\
\hline 0 & $67 \pm 3$ & $15 \pm 3$ \\
\hline 1 & $43.5 \pm 5$ & $20 \pm 1$ \\
\hline 2 & $22.5 \pm 4$ & $34 \pm 6$ \\
\hline 3 & $1 \pm 1$ & $45 \pm 14$ \\
\hline 4 & $2 \pm 1$ & $80 \pm 3$ \\
\hline
\end{tabular}

incorporation and increase in the percentage of SA- $\beta$-gal positively stained cells (data not shown).

Subsequently, we investigated the expression of known biochemical markers of senescence in order to characterise $\mathrm{H}_{2} \mathrm{O}_{2}$-senescent nucleus pulposus cells at the molecular level. In accordance to our findings concerning BrdU incorporation and SA- $\beta$-gal staining mentioned above, $\mathrm{H}_{2} \mathrm{O}_{2}$-senescent cells had higher expression levels of p53, p16 ${ }^{\mathrm{INK} 4 \mathrm{a}}$ and $\mathrm{p} 21^{\mathrm{WAF} 1}$ than control cells, while only the hypophosphorylated form of $\mathrm{pRb}$ was present (Fig. 6B), consistent with the observed ceased proliferation. Interestingly, when the mean TRF was measured (Fig. 6C), we found a small but non-significant decrease $(p=0.74)$ in $\mathrm{H}_{2} \mathrm{O}_{2}$-treated cells (meanTRF $=9.53 \pm 1.36 \mathrm{~Kb})$ in comparison to the control cells (meanTRF $=9.95 \pm 0.09 \mathrm{~Kb})$. As can be seen in Fig. 7A, incubation of nucleus pulposus cells with $2 \mathrm{mM} \mathrm{NAC}$ decreased significantly the $\mathrm{H}_{2} \mathrm{O}_{2}$-induced ROS levels. When we serially exposed cells to $\mathrm{H}_{2} \mathrm{O}_{2}$, the presence of $2 \mathrm{mM}$ NAC was able to limit the percentage of senescent cells to a high degree (Fig. 7B), thus validating the ROSmediated nature of the $\mathrm{H}_{2} \mathrm{O}_{2}$-induced senescence in nucleus pulposus cells.

\section{Prematurely senescent nucleus pulposus cells by} $\mathrm{H}_{2} \mathrm{O}_{2}$ express a catabolic phenotype

In an attempt to better characterise the $\mathrm{H}_{2} \mathrm{O}_{2}$-senescent nucleus pulposus cells, we investigated the expression profile of several genes that were either markers of senescence and oxidative stress response or encoded proteins regulating ECM production and degradation in the intervertebral disc. Real-time PCR analysis revealed the up-regulation of senescent markers, ROS-induced and ECM-degrading enzymes and the down-regulation of ECM structural components (Fig. 8). In detail, the mRNA levels of $\mathrm{p} 16^{\mathrm{INK} 4 \mathrm{a}}$ and $\mathrm{p} 21^{\mathrm{WAF} 1}$ were shown to increase $\sim 3$ - and 5.5-fold, respectively in accordance to the senescent phenotype of $\mathrm{H}_{2} \mathrm{O}_{2}$-treated cells. In the set of genes encoding enzymes related to oxidative stress that were examined, two of them [superoxide dismutase (SOD) and cyclooxygenase 2 (COX2)] were found to present increased expression levels $(\sim 2$-fold), while one (catalase) was down-regulated. Finally, the produced catabolic phenotype of $\mathrm{H}_{2} \mathrm{O}_{2}$-senescent nucleus pulposus cells was supported by the up-regulation of several ECMdegrading enzymes at the same time that genes encoding components of the disc ECM had lower mRNA levels than the control cells. More specifically, ADAMTS-5, MMP-1, 

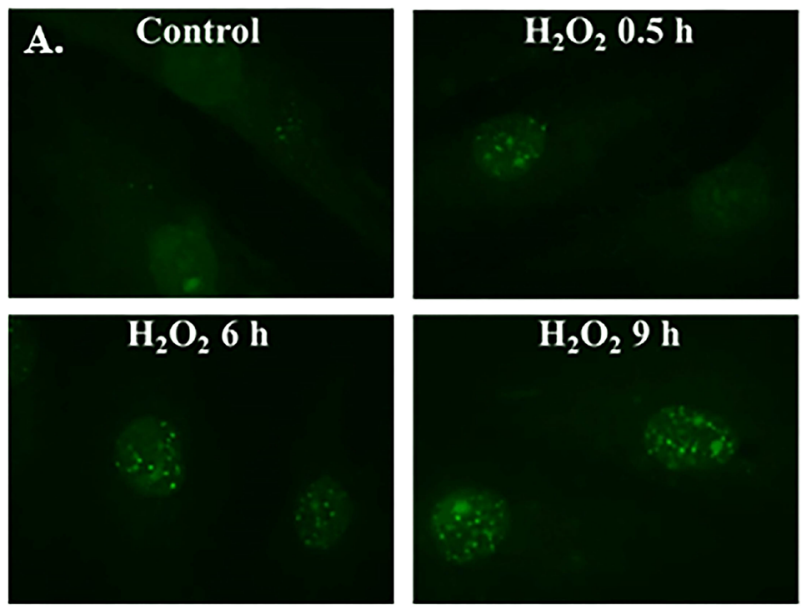

B.

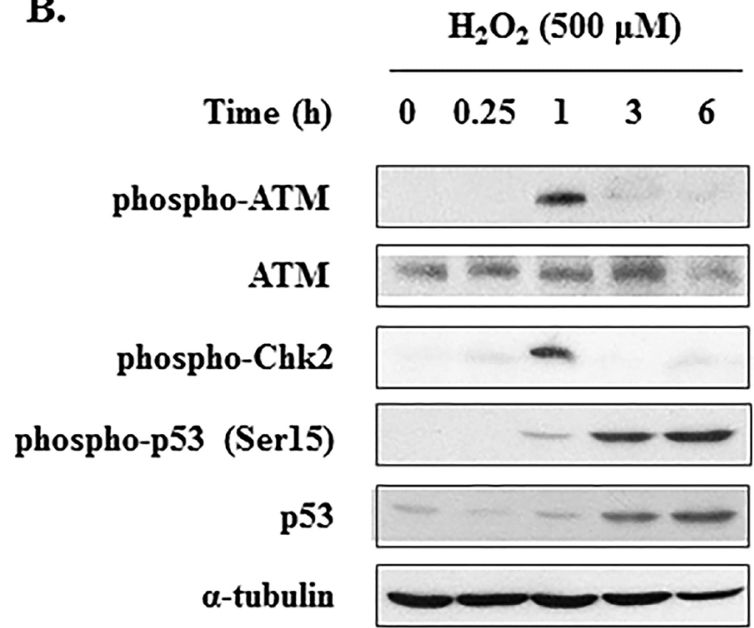

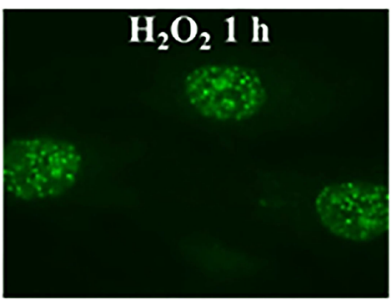

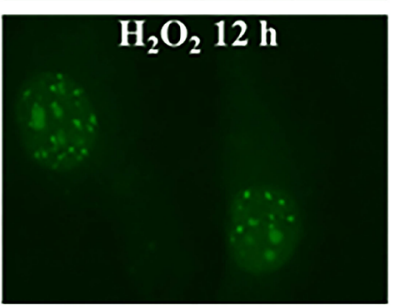

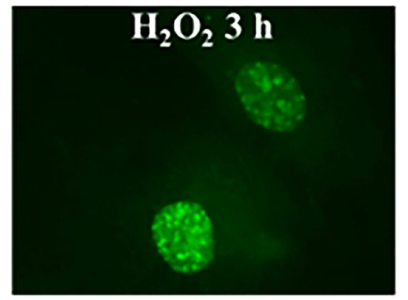

$\mathrm{H}_{2} \mathrm{O}_{2} 24 \mathrm{~h}$

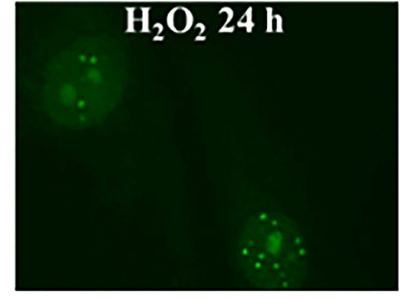

$\mathrm{H}_{2} \mathrm{O}_{2}(500 \mu \mathrm{M})$

$\begin{array}{lllllllll}\text { Time (h) } & 0 & 0.25 & 1 & 3 & 6 & 9 & 12 & 24\end{array}$
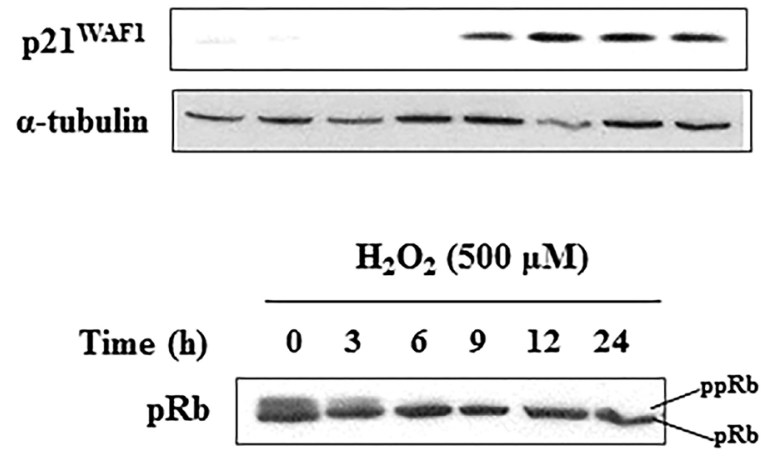

C.

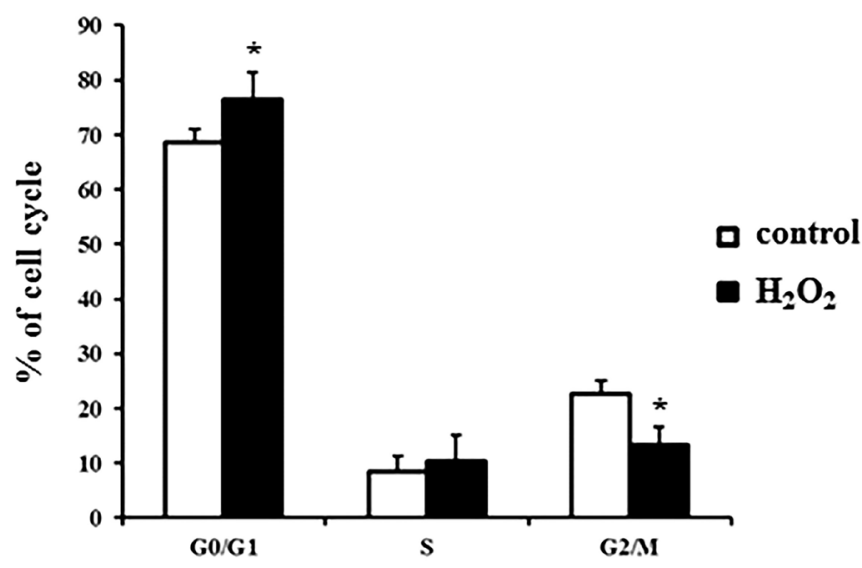

Fig. 4. $\mathrm{H}_{2} \mathrm{O}_{2}$ is genotoxic and triggers a DNA repair response to human nucleus pulposus cells. (A) Cells were plated on glass coverslips and treated with $500 \mu \mathrm{M} \mathrm{H}_{2} \mathrm{O}_{2}$ for the time points shown. After fixation, samples were labelled with an antibody for the phosphorylated form of histone H2A.X on Ser139 followed by an incubation step with an anti-rabbit FITC-conjugated secondary antibody. Representative microscopy images are shown here. (B) Cells were treated with $\mathrm{H}_{2} \mathrm{O}_{2}$ and protein extraction was performed at the designated time points. Samples were analysed by western blotting for the phosphorylated form of ATM on Ser1981, the phosphorylated form of Chk2 on Thr68, the phosphorylated form of p53 on Ser15, p2 $1^{\mathrm{WAF} 1}$ and pRb. Western blot analysis for $\alpha$-tubulin served as the loading control. Experiments were repeated there times and representative blots are depicted. (C) Cells were treated with $500 \mu \mathrm{M} \mathrm{H}_{2} \mathrm{O}_{2}$ for $24 \mathrm{~h}$ before fixation. Fixed cells were stained with propidium iodide and analysed by flow cytometry. Values presented in the graph are means \pm standard deviations from three experiments. Asterisks denote statistically significant differences in comparison to the control (Mann-Whitney test, $p<0.05$ ). 


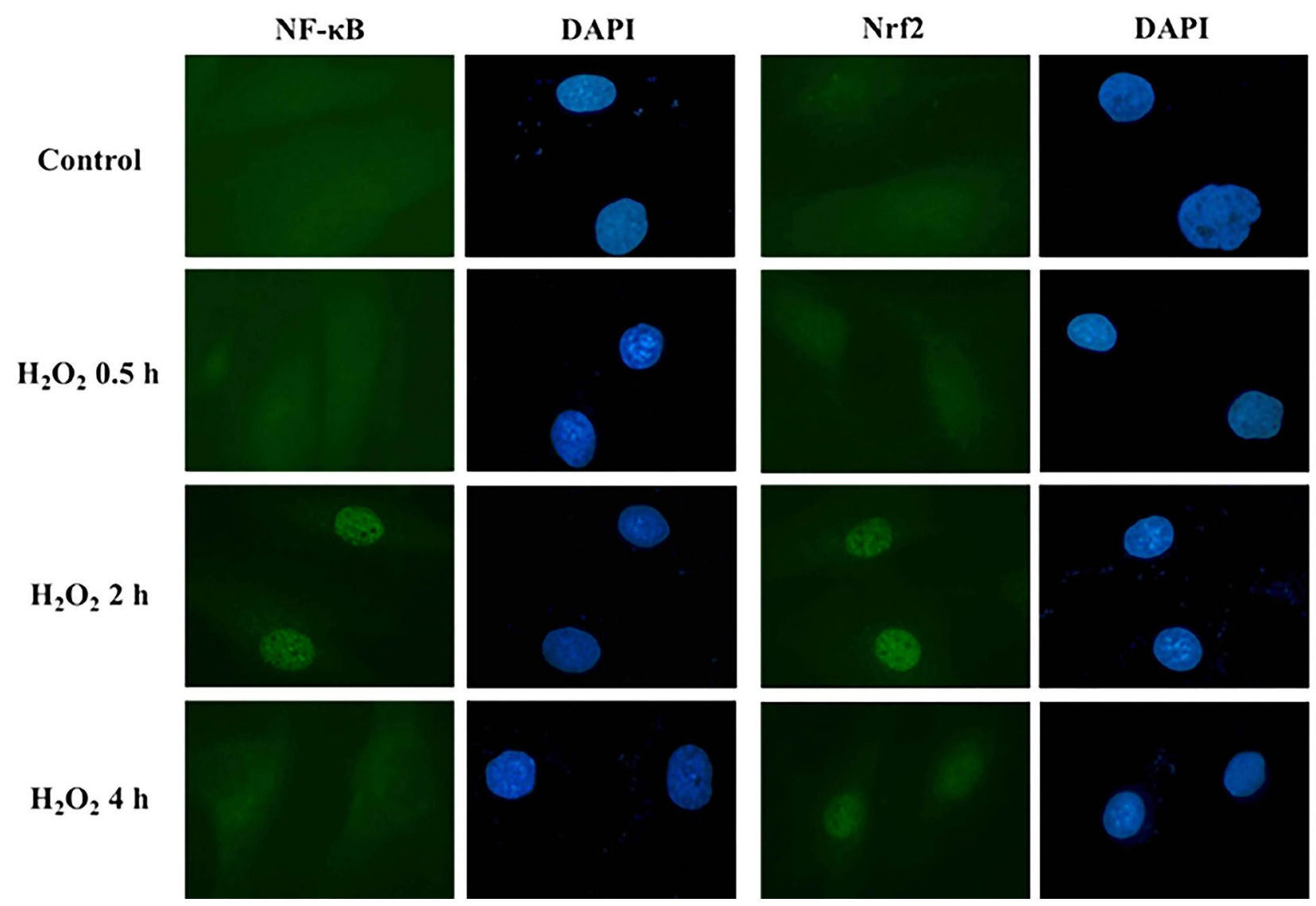

Fig. 5. Nuclear translocation of NF- $\mathrm{B}$ p 65 subunit and $\mathrm{Nrf} 2$ after exposure of human nucleus pulposus cells to $\mathrm{H}_{2} \mathrm{O}_{2}$. Cells were grown on glass coverslips and they were then exposed to $500 \mu \mathrm{M} \mathrm{H}_{2} \mathrm{O}_{2}$ for the designated time periods. Samples were fixed and labelled using antibodies against the p65 subunit of NF-kB and Nrf2 and counterstained with DAPI. The pictures are representative of three independent experiments.

MMP-2 and MMP-9 were significantly up-regulated in $\mathrm{H}_{2} \mathrm{O}_{2}$-senescent nucleus pulposus cells. On the other hand, all intervertebral disc proteoglycans tested here - aggrecan (the major ECM constituent of the nucleus pulposus), biglycan, decorin and versican - were found to be downregulated along with an observed decrease in the mRNA levels of TIMP-1, -2 and -3 .

\section{Discussion}

The intervertebral disc is characterised by the appearance of signs of degeneration relatively early in life, compared to the majority of the other tissues in the body. This is most probably due to the effect of the several intense stresses the disc is exposed to. Even though one of the major features of the normal intervertebral disc is the absence of vascularisation - leading to relatively hypoxic conditions - disc cells still use oxidative phosphorylation for their energy production, with ROS being the main by-product (Vo et al., 2013). In addition, ROS can be produced in response to cytokines such as interleukins (ILs), TNF- $\alpha$ or TGF- $\beta$, known to be expressed in the intervertebral disc, or to various DNA-damaging insults, such as ionising radiation and genotoxic drugs. On the other hand, the lack of vascularisation may result in the accumulation of these waste products and the continuous damage of cellular macromolecules. Taking these into account, several in vivo studies have assessed and verified the presence of oxidative stress and the increased concentration of oxidation products in aged intervertebral discs (Hou et al., 2014; Nerlich et al., 2007; Nerlich et al., 1997). Oxidative stress in the disc is manifested in the form of $\mathrm{H}_{2} \mathrm{O}_{2}$, as shown in human nucleus pulposus specimens by Kim et al. (2009). Therefore, here we investigated the effect of exogenously supplied $\mathrm{H}_{2} \mathrm{O}_{2}$ on the viability, proliferation and senescence of nucleus pulposus cells, as well as the underlying molecular mechanisms of the observed phenomena.

We showed that $\mathrm{H}_{2} \mathrm{O}_{2}$ considerably increased intracellular ROS levels in disc cells in a dose-dependent manner. In all $\mathrm{H}_{2} \mathrm{O}_{2}$ concentrations tested, ROS levels peaked early after stimulation and declined thereafter. This decrease most probably stemmed from the activation of antioxidant mechanisms, including Nrf2 activation, evidenced by its translocation into the nucleus. Cytotoxicity studies using the MTT assay indicated that the viability of the cells remained close to the control levels at $\mathrm{H}_{2} \mathrm{O}_{2}$ concentrations up to $600 \mu \mathrm{M}$, after which it declined sharply.

The nucleus pulposus of the intact intervertebral disc is characterised by a very low rate of cell proliferation (Johnson and Roberts, 2003) and an extremely low cell 
A.
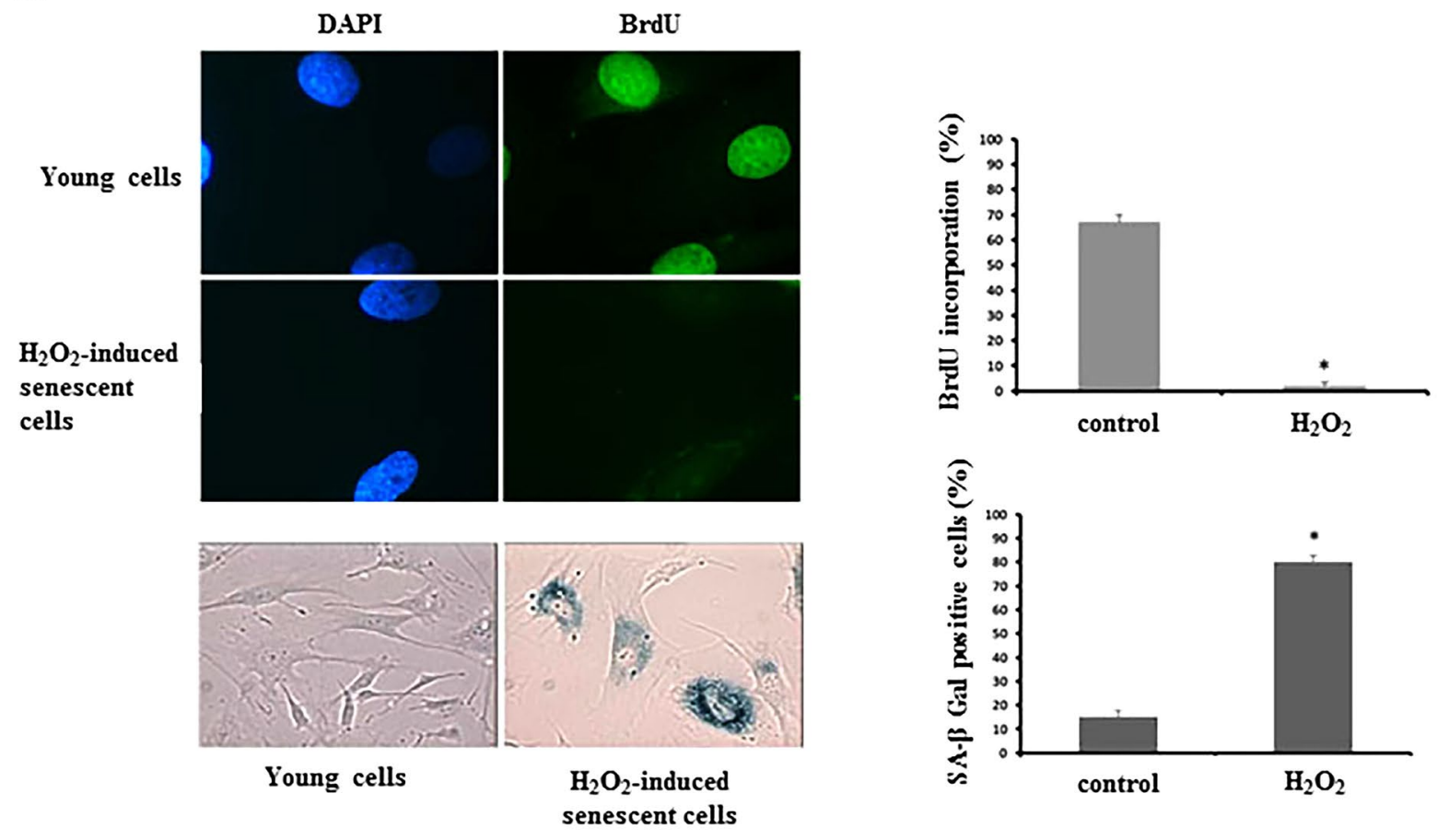

B.

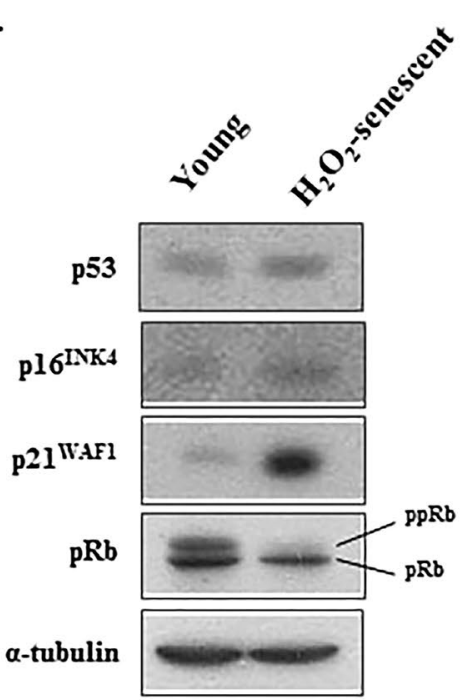

C.

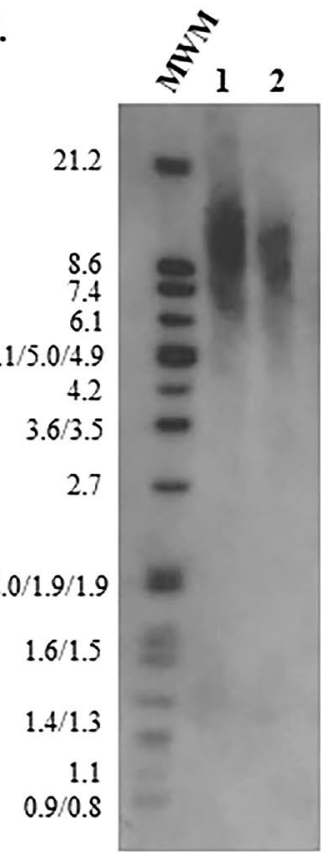

Fig. 6. Repeated exposure of human nucleus pulposus cells to $\mathrm{H}_{2} \mathrm{O}_{2}$ leads to premature senescence. (A) Cells were plated on glass coverslips after four consecutive exposures to $500 \mu \mathrm{M} \mathrm{H}_{2} \mathrm{O}_{2}$. For the estimation of BrdU incorporation, $\mathrm{BrdU}$ was added at a concentration of $50 \mu \mathrm{M}$ for $48 \mathrm{~h}$ before fixation and labelling with an anti-BrdU-FITC antibody, while for SA- $\beta$-gal staining cells were directly fixed. Samples were visualised and cells were counted under a fluorescence or phase contrast microscope, respectively. In the graphs mean values \pm standard deviations are presented deriving from three independently conducted experiments. Asterisks represent statistically significant differences in comparison to the control (Student's $t$-test, $p<0.05$ ). (B) Cells were plated on 60-mm dishes after four serial exposures to $500 \mu \mathrm{M} \mathrm{H}_{2} \mathrm{O}_{2}$ and total protein extracts were collected. Western blotting was performed for the total levels of p53, p16 ${ }^{\text {INK4a }}$, p2 $1^{\text {WAF1 }}$ and $\mathrm{pRb}$. The expression levels of $\alpha$-tubulin were examined as a loading control. Blots presented are selected among three experiments. (C) Control and $\mathrm{H}_{2} \mathrm{O}_{2}$-senescent cells were plated on 100 -mm dishes before genomic extraction and southern blotting for the determination of the meanTRF. The gel presented is representative of three independent repetitions. Lane 1: Control, Lane 2: Cells exposed four consecutive times to $500 \mu \mathrm{M} \mathrm{H}_{2} \mathrm{O}_{2}$ as described in Materials and Methods. 
A.

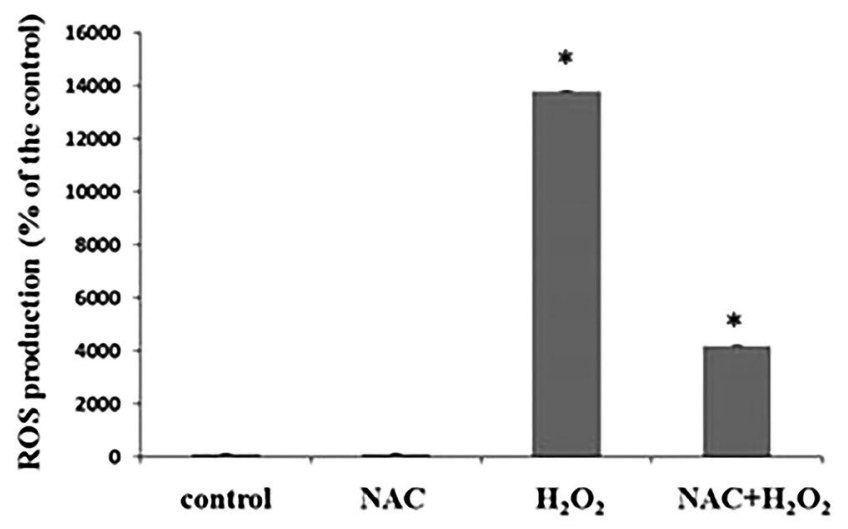

B.

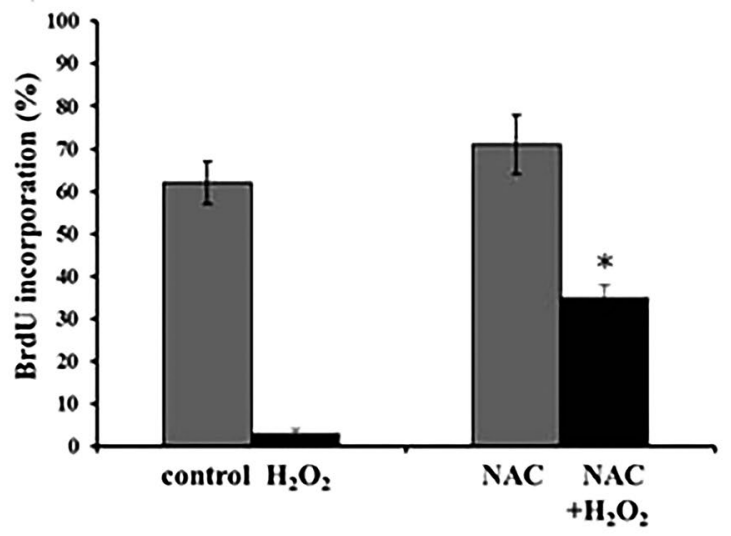

Fig. 7. The $\mathrm{H}_{2} \mathrm{O}_{2}$-induced premature senescence of human nucleus pulposus cells is ROS-mediated. (A) Cells were grown in 96-well plates until confluence and they were then incubated with $2 \mathrm{mM} \mathrm{NAC}$ for $16 \mathrm{~h} \mathrm{H}_{2} \mathrm{O}_{2}(500 \mu \mathrm{M})$ was added along with $10 \mu \mathrm{M}$ DCFH-DA for $15 \mathrm{~min}$ and measurements were recorded. (B) Cells on glass coverslips were subjected to the $\mathrm{H}_{2} \mathrm{O}_{2}$-induced premature senescence protocol in the presence or not of $2 \mathrm{mM} \mathrm{NAC}$ and $\mathrm{BrdU}$ incorporation was estimated in the fixed samples. Data presented in the graphs are the mean values \pm standard deviations of three separate experiments and asterisks pinpoint statistically significant differences in comparison to the untreated control (A) or to the $\mathrm{H}_{2} \mathrm{O}_{2}$-treated sample in the absence of NAC (B) (Student's $t$-test, $p<0.05$ ).

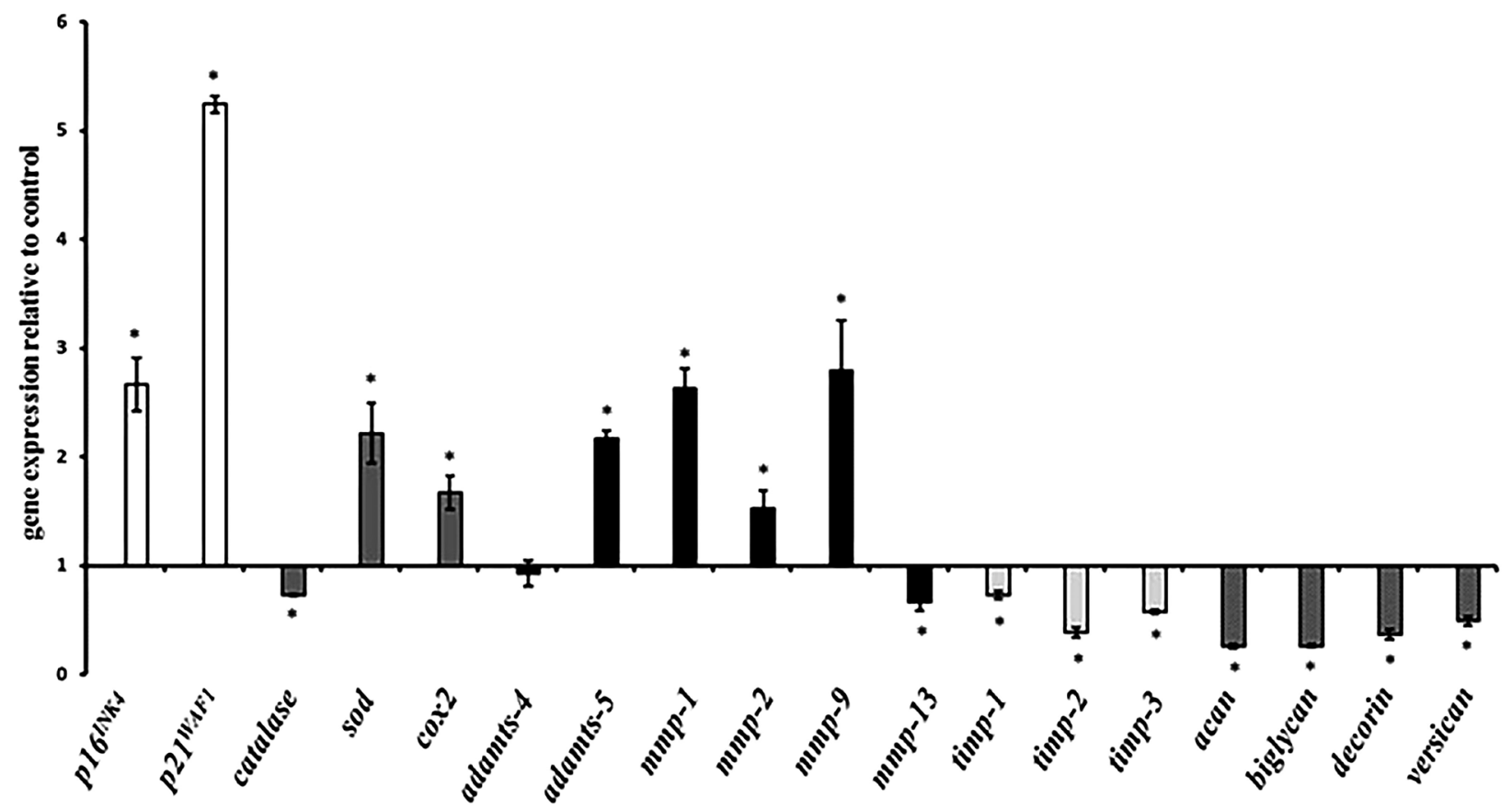

Fig. 8. $\mathrm{H}_{2} \mathrm{O}_{2}$-senescent nucleus pulposus cells show a catabolic phenotype. Cells were exposed to $500 \mu \mathrm{M} \mathrm{H}_{2} \mathrm{O}_{2}$ four consecutive times and they were then plated in 100-mm dishes. Total RNA was extracted and mRNA levels of the designated genes were measured by quantitative RT-PCR. Mean Ct values of target genes in each sample were normalised to that of GAPDH. Ratios of the expression levels of the senescent cells to those of the untreated control are presented as mean values \pm standard deviations of three independent experiments. Statistically significant differences (Student's $t$-test, $p<0.05$ ) are marked by asterisks.

density, most probably due to the exceptionally adverse nutritional conditions in this non-vascularised tissue (Urban et al., 2004). The repression of this cell population at an extremely low number in the intact tissue can be the combined outcome of many parameters, such as the nutritional status, the particular ECM components, the lack of exogenous growth factors, as well as the multiple stresses these cells are exposed to. We demonstrated here that oxidative stress (in the form of $\mathrm{H}_{2} \mathrm{O}_{2}$ ) can drastically inhibit intervertebral disc cell proliferation in a dosedependent manner. Similarly, we have shown that another major stress, i.e. hyperosmolality, also inhibits nucleus pulposus cells' proliferation and decreases the proliferative effect of several growth factors, such as PDGF or IGF-I 
(Mavrogonatou and Kletsas, 2009; Mavrogonatou and Kletsas, 2010). The above are in favour of the hypothesis that the presence of exogenous stresses, including oxidative stress, in the normal disc may serve in holding the cell population down to a certain level, thus, among others, ensuring adequate nutrition and cell viability. For the rest of our experiments we selected the highest $\mathrm{H}_{2} \mathrm{O}_{2}$ concentration with practically no cytotoxic effect $(500 \mu \mathrm{M})$. However, it is interesting to note that the actual intracellular $\mathrm{H}_{2} \mathrm{O}_{2}$ concentration in Hela cells has been measured to be $\sim 650$ fold lower than the initial concentration exogenously supplied (Huang and Sikes, 2014), which means that the observed phenomena in human nucleus pulposus cells could have been triggered by an intracellular $\mathrm{H}_{2} \mathrm{O}_{2}$ concentration $<1 \mu \mathrm{M}$.

An immediate effect of $\mathrm{H}_{2} \mathrm{O}_{2}$ was found to be the activation of PI3K/Akt and of all three MAPK signalling pathways, i.e. p38 MAPK, ERK and JNK, a typical cellular response to exogenous stresses. All pathways were activated within 15 min after stimulation with $\mathrm{H}_{2} \mathrm{O}_{2}$, while they followed different kinetics of dephosphorylation. According to previous reports, all pathways mentioned above are triggered in intervertebral disc cells by several stimuli, such as inflammatory cytokines, growth factors, hypoxia or hyperosmotic conditions, and they have different functions in cell and tissue physiology (Studer et al., 2008; Wuertz et al., 2012). ERK and Akt pathways have been reported to be stimulated by oxidative stress in other cell systems, as well (e.g. trabecular meshwork cells), in which their inhibition results in decreased cell viability (Awai-Kasaoka et al., 2013), most probably due to the activation of Nrf2, as an antioxidant defence (Bak et al., 2012; Park et al., 2013).

Oxidative stress was shown here to have a direct genotoxic effect, revealed by the formation of $\gamma \mathrm{H} 2 \mathrm{~A} . \mathrm{X}$ foci in the nuclei of disc cells, as soon as $30 \mathrm{~min}$ after treatment with $\mathrm{H}_{2} \mathrm{O}_{2}$. The accumulation of the foci peaked at approx. $3 \mathrm{~h}$ and then started to decline, possibly due to the activation of DNA repair mechanisms. However, even $24 \mathrm{~h}$ later several foci remained. Double strand break (DSB) formation, as indicated by the accumulation of $\gamma \mathrm{H} 2 \mathrm{~A} . \mathrm{X}$ foci, was followed by the so-called DNA damage response (DDR), characterised by the activation of the ATM-Chk2p53-p2 $1^{\text {WAF1 }}-$ pRb pathway, that led to the inhibition of cell proliferation by blocking the G1-S transition of the cell cycle. This finding is in accordance with the G1 phase arrest observed in other cell types after exposure to $\mathrm{H}_{2} \mathrm{O}_{2}$ (Bladier et al., 1997; Deshpande et al., 2002; Park, 2013). ATM activation is in general considered as a direct effect of DSB formation through the action of the Mre11-Rad50-Nbs1 (MRN) DNA repair complex, thus orchestrating the DNA repair response. However, it has been proposed that ATM activation by DSBs is inhibited in the presence of $\mathrm{H}_{2} \mathrm{O}_{2}$, as the latter blocks the ability of the MRN to bind to damaged DNA; in this case, ATM is activated by direct oxidation (Guo et al., 2010a; Guo et al., 2010b). On the other hand, p38 MAPK (also activated by $\mathrm{H}_{2} \mathrm{O}_{2}$ ) can directly activate the ATM downstream target $\mathrm{p} 53$, as well as p16 $6^{\mathrm{INK} 4 \mathrm{a}}$, and consequently block cell proliferation (Han and Sun, 2007). All the above indicate that the anti-proliferative effect of oxidative stress on nucleus pulposus cells results from a cross-talk of several signalling pathways.

Exposure of intervertebral disc cells to $\mathrm{H}_{2} \mathrm{O}_{2}$ led to the activation of the transcription factor NF- $\mathrm{KB}$, as demonstrated by the nuclear translocation of its $\mathrm{p} 65$ subunit. NF-kB is typically activated by stress and cellular damage (Wuertz et al., 2012), under oxidative (Bubici et al., 2006) and genotoxic (Wu et al., 2006) stresses, leading to the transcription of inflammatory genes (Pedruzzi et al., 2012). Interestingly and in agreement with our data, NF$\kappa \mathrm{B}$ has been reported to be activated in adult intervertebral disc samples in close correlation with CML accumulation [the latter being a marker of oxidative stress (Nerlich et al., 2007)], thus supporting its role in intervertebral disc degeneration. On the other hand, we also observed the nuclear translocation of Nrf2, a basic leucine zipper transcription factor that regulates the expression of antioxidant proteins, as a response to $\mathrm{H}_{2} \mathrm{O}_{2}$ in order to protect cells against oxidative damage. Based on several reports, we can hypothesise that this translocation stems from the activation of the pathway(s) found to be activated by oxidative stress, such as the MAPKs (de Bittencourt Pasquali et al., 2013; Owuor and Kong, 2002), Akt (Sykiotis et al., 2011) or even ATM (Li et al., 2004). The role of the simultaneous activation of these antagonistic pathways in disc physiology in response to stress requires further investigation.

Normal cells have a limited lifespan when cultured in vitro. After a certain number of population doublings, characteristic for each individual cell strain, the cells enter a state termed senescence, characterised by their inability to proliferate. This type of senescence, called replicative senescence (RS), is the result of the gradual shortening of telomeres, the end of the chromosomes. At a critical point this shortening is perceived by the cells as a DNA damage, thus triggering a classical DDR, characterised by the activation of the ATM-Chk2-p53-p2 $1^{\mathrm{WAF} 1}$ axis that leads to the hypophosphorylation of the $\mathrm{pRb}$ protein and consequently to the inability of the cells to undergo the G1-S transition in the cell cycle (Campisi and d'Adda di Fagagna, 2007). Alternatively, cells when exposed repeatedly to subcytotoxic doses of several genotoxic stresses, such as UV or ionising radiation, genotoxic drugs or oxidative stress (Papadopoulou and Kletsas, 2011; Roninson, 2002; Toussaint et al., 2000) or even after the overexpression of certain oncogenes (Bartkova et al., 2006; Serrano et al., 1997) can undergo a type of senescence termed stress-induced premature senescence (SIPS). Interestingly, the activation of a DDR is a central motif in most types of senescence. Roberts et al. (2006a) have shown for the first time that senescent cells accumulate in the aged and degenerated discs, and this finding has been further verified by several laboratories (Gruber et al., 2007; Kim et al., 2009; Le Maitre et al., 2007a). As it is well known that the intervertebral disc is characterised by a very low proliferative rate (Johnson and Roberts, 2003), it is more probable that senescence in this tissue is of the SIPS type due to exogenous stresses (Kletsas, 2009). Here, we found that exposure to repeated subcytotoxic doses of $\mathrm{H}_{2} \mathrm{O}_{2}$ provoked premature senescence to human disc cells, shown 
by their inability to synthesise DNA and by the increased number of cells positive to SA- $\beta$-gal staining. This effect increased gradually with the number of the exposures to $\mathrm{H}_{2} \mathrm{O}_{2}$ and after four consecutive doses more than $95 \%$ of the cells could be driven to senescence. Interestingly, we observed an increased number of senescent cells even as a response to much lower $\mathrm{H}_{2} \mathrm{O}_{2}$ concentrations, but after a higher number of exposures. These $\mathrm{H}_{2} \mathrm{O}_{2}$-senescent disc cells overexpressed classical senescence markers, such as $\mathrm{p} 53$, the cell cycle inhibitors $\mathrm{p} 21^{\mathrm{WAF} 1}$ and $\mathrm{p} 16^{\mathrm{INK} 4 \mathrm{a}}$ and the hypophosphorylated $\mathrm{pRb}$. It has been reported by von Zglinicki et al. that oxidative stress leads to telomere shortening in human fibroblasts (von Zglinicki et al., 2000). When we measured the length of telomeres in $\mathrm{H}_{2} \mathrm{O}_{2}$-senescent intervertebral disc cells we did not find any statistically significant decrease. Our observations are in line with those of Chen et al. claiming that the senescent phenotype is uncoupled with telomere shortening in $\mathrm{H}_{2} \mathrm{O}_{2}$ treated fibroblasts (Chen et al., 2001). However, these authors hypothesised that cell replication is needed for telomere shortening in response to oxidative stress (Chen et al., 2001). As our experiments have been conducted in confluent (non-proliferating) cultures, we cannot exclude the possibility that a combination of $\mathrm{H}_{2} \mathrm{O}_{2}$-treatment and cell replications would lead to shorter telomeres in nucleus pulposus cells, as well.

Beyond their inability to proliferate, representing a major obstacle to tissue repair processes, senescent cells are also characterised by a catabolic phenotype. Several studies, performed mainly in fibroblasts, have reported that senescent cells overexpress matrix degrading enzymes, inflammatory cytokines and other inflammatory molecules, and it has been proposed that due to this catabolic and inflammatory phenotype they could negatively affect tissue homeostasis (Campisi and d'Adda di Fagagna, 2007). Accordingly, we investigated the gene expression profile of nucleus pulposus cells that became senescent after continuous exposures to $\mathrm{H}_{2} \mathrm{O}_{2}$. It should be mentioned that the differences observed at the $\mathrm{H}_{2} \mathrm{O}_{2}$-induced terminally senescent stage were not vast. This finding was not surprising, given that cells may have become adapted after a long residence to the stressful environment, ultimately exhibiting a lower that then initial response, but constant residual differential gene expression. As expected, we found an increase in the expression of two classical senescence markers, the cyclin-dependent kinase inhibitors p $21^{\mathrm{WAF} 1}$ and $\mathrm{p} 16^{\mathrm{INK} 4 \mathrm{a}}$, in senescent cells compared to young ones. We also observed a decrease in catalase and an increase in SOD expression, partly in agreement with data reported for senescent skin fibroblasts (Kaneko et al., 2001). The expression of COX2 was also found up-regulated. This is in accordance to the results of Zdanov et al. (2009) who reported similar results in fibroblasts; these authors have also demonstrated that this up-regulation is mediated by p53, shown here to be up-regulated in senescent cells after exposure to oxidative stress.

Nucleus pulposus cells are considered critical regulators of the ECM in this tissue, composed mainly of proteoglycans, the most prominent being aggrecan (Roughley et al., 2002). Gene expression analysis of senescent nucleus pulposus cells indicated an intense down- regulation of aggrecan, as well as of other proteoglycans, such as biglycan, decorin and versican. In addition to this anti-anabolic phenotype, catabolic markers were also induced. More specifically, MMP-1, MMP-2, MMP-9 and ADAMTS-5 were up-regulated, while ADAMTS-4 was found to be unchanged and MMP-13 down-regulated. Although in general TIMP expression parallels that of MMPs, we found that TIMP-1, TIMP-2, and TIMP-3 known to inhibit both MMPs, as well as ADAMTSs - were also down-regulated in senescent intervertebral disc cells, indicating a generalised catabolic phenotype. Numerous in vivo studies have reported similar results on the upregulation of several MMPs and of ADAMTS-5, or the down-regulation of aggrecan and decorin (Le Maitre et al., 2004; Pockert et al., 2009; Roberts et al., 2000; Singh et al., 2009; Sivan et al., 2014). However, these in vivo studies have demonstrated an increase of TIMP-1 and TIMP2, biglycan and ADAMTS-4, in contrast to our results, suggesting that the expression of these genes in vivo may be regulated not only by the senescent status of disc cells, but also by other factors of their local microenvironment. On the other hand, in vitro and organotypic studies have shown that oxidative stress, provoked in an environment with increased $\mathrm{O}_{2}$, leads to an increase of ADAMTS-5, MMP-1 and MMP-3 (Nasto et al., 2013). The above indicate that oxidative stress-mediated premature cellular senescence may affect nucleus pulposus homeostasis due to the catabolism of its ECM components, thus compromising the structural integrity of this tissue.

In conclusion, our data indicate that oxidative stress, typically met in the aged intervertebral disc, can inhibit disc cells' proliferation and provoke their premature senescence. The catabolic phenotype of these senescent cells may contribute to the degeneration of the tissue. Based on these findings, further studies are needed to establish the putative application of antioxidants as treatments that could efficiently decelerate intervertebral disc degeneration.

\section{Acknowledgements}

This work was supported by the European Union FP7 ("GENODISC" project, HEALTH-F2-2008-201626).

\section{References}

Awai-Kasaoka N, Inoue T, Kameda T, Fujimoto T, Inoue-Mochita M, Tanihara H (2013) Oxidative stress response signaling pathways in trabecular meshwork cells and their effects on cell viability. Mol Vis 19: 1332-1340.

Bak MJ, Jun M, Jeong WS (2012) Procyanidins from wild grape (Vitis amurensis) seeds regulate ARE-mediated enzyme expression via Nrf2 coupled with p38 and PI3K/ Akt pathway in HepG2 cells. Int J Mol Sci 13: 801-818.

Bartkova J, Rezaei N, Liontos M, Karakaidos P, Kletsas D, Issaeva N, Vassiliou LV, Kolettas E, Niforou K, Zoumpourlis VC, Takaoka M, Nakagawa H, Tort F, Fugger K, Johansson F, Sehested M, Andersen CL, Dyrskjot L, Orntoft T, Lukas J, Kittas C, Helleday T, Halazonetis TD, Bartek J, Gorgoulis VG (2006) Oncogene-induced 
senescence is part of the tumorigenesis barrier imposed by DNA damage checkpoints. Nature 444: 633-637.

Bladier C, Wolvetang EJ, Hutchinson P, de Haan JB, Kola I (1997) Response of a primary human fibroblast cell line to $\mathrm{H}_{2} \mathrm{O}_{2}$ : senescence-like growth arrest or apoptosis? Cell Growth Differ 8: 589-598.

Bubici C, Papa S, Pham CG, Zazzeroni F, Franzoso G (2006) The NF-kappaB-mediated control of ROS and JNK signaling. Histol Histopathol 21: 69-80.

Campisi J, d'Adda di Fagagna F (2007) Cellular senescence: when bad things happen to good cells. Nat Rev Mol Cell Biol 8: 729-740.

Chen QM, Prowse KR, Tu VC, Purdom S, Linskens MH (2001) Uncoupling the senescent phenotype from telomere shortening in hydrogen peroxide-treated fibroblasts. Exp Cell Res 265: 294-303.

de Bittencourt Pasquali MA, Gelain DP, ZeidanChulia F, Pires AS, Gasparotto J, Terra SR, Moreira JC (2013) Vitamin A (retinol) downregulates the receptor for advanced glycation endproducts (RAGE) by oxidantdependent activation of p38 MAPK and NF-kB in human lung cancer A549 cells. Cell Signal 25: 939-954.

Deshpande NN, Sorescu D, Seshiah P, Ushio-Fukai M, Akers M, Yin Q, Griendling KK (2002) Mechanism of hydrogen peroxide-induced cell cycle arrest in vascular smooth muscle. Antioxid Redox Signal 4: 845-854.

Freemont AJ (2009) The cellular pathobiology of the degenerate intervertebral disc and discogenic back pain. Rheumatology (Oxford) 48: 5-10.

Gruber HE, Ingram JA, Norton HJ, Hanley EN, Jr. (2007) Senescence in cells of the aging and degenerating intervertebral disc: immunolocalization of senescenceassociated beta-galactosidase in human and sand rat discs. Spine (Phila Pa 1976) 32: 321-327.

Guo Z, Deshpande R, Paull TT (2010a) ATM activation in the presence of oxidative stress. Cell Cycle 9: 48054811.

Guo Z, Kozlov S, Lavin MF, Person MD, Paull TT (2010b) ATM activation by oxidative stress. Science 330: 517-521.

Han J, Sun P (2007) The pathways to tumor suppression via route p38. Trends Biochem Sci 32: 364-371.

Harley CB, Futcher AB, Greider CW (1990) Telomeres shorten during ageing of human fibroblasts. Nature 345: 458-460.

Hou G, Lu H, Chen M, Yao H, Zhao H (2014) Oxidative stress participates in age-related changes in rat lumbar intervertebral discs. Arch Gerontol Geriatr 59: 665-669.

Huang BK, Sikes HD (2014) Quantifying intracellular hydrogen peroxide perturbations in terms of concentration. Redox Biol 2: 955-962.

Johnson WEB, Roberts S (2003) Human intervertebral disc cell morphology and cytoskeletal composition: a preliminary study of regional variations in health and disease. J Anat 203: 605-612.

Kaneko T, Tahara S, Taguchi T, Kondo H (2001) Accumulation of oxidative DNA damage, 8-oxo-2'deoxyguanosine, and change of repair systems during in vitro cellular aging of cultured human skin fibroblasts. Mutat Res 487: 19-30.
Katz JN (2006) Lumbar disc disorders and low-back pain: socioeconomic factors and consequences. J Bone Joint Surg Am 88 Suppl 2: 21-24.

Kim KW, Chung HN, Ha KY, Lee JS, Kim YY (2009) Senescence mechanisms of nucleus pulposus chondrocytes in human intervertebral discs. Spine J 9: 658-666.

Kletsas D (2009) Senescent cells in the intervertebral disc: numbers and mechanisms. Spine J 9: 677-678.

Konstantonis D, Papadopoulou A, Makou M, Eliades T, Basdra EK, Kletsas D (2013) Senescent human periodontal ligament fibroblasts after replicative exhaustion or ionizing radiation have a decreased capacity towards osteoblastic differentiation. Biogerontology 14: 741-751.

Le Maitre CL, Freemont AJ, Hoyland JA (2004) Localization of degradative enzymes and their inhibitors in the degenerate human intervertebral disc. J Pathol 204: 47-54.

Le Maitre CL, Freemont AJ, Hoyland JA (2006) Human disc degeneration is associated with increased MMP 7 expression. Biotech Histochem 81: 125-131.

Le Maitre CL, Freemont AJ, Hoyland JA (2007a) Accelerated cellular senescence in degenerate intervertebral discs: a possible role in the pathogenesis of intervertebral disc degeneration. Arthritis Res Ther 9: R45.

Le Maitre CL, Pockert A, Buttle DJ, Freemont AJ, Hoyland JA (2007b) Matrix synthesis and degradation in human intervertebral disc degeneration. Biochem Soc Trans 35: 652-655.

Li B, Wang X, Rasheed N, Hu Y, Boast S, Ishii T, Nakayama K, Nakayama KI, Goff SP (2004) Distinct roles of c-Abl and Atm in oxidative stress response are mediated by protein kinase C delta. Genes Dev 18: 1824-1837.

Livak KJ, Schmittgen TD (2001) Analysis of relative gene expression data using real-time quantitative PCR and the 2(-Delta Delta C(T)) Method. Methods 25: 402-408.

Lu T, Finkel T (2008) Free radicals and senescence. Exp Cell Res 314: 1918-1922.

Luoma K, Riihimaki H, Luukkonen R, Raininko R, Viikari-Juntura E, Lamminen A (2000) Low back pain in relation to lumbar disc degeneration. Spine (Phila Pa 1976) 25: 487-492.

Mavrogonatou E, Angelopoulou MT, Kletsas D (2014) The catabolic effect of TNFalpha on bovine nucleus pulposus intervertebral disc cells and the restraining role of glucosamine sulfate in the TNFalpha-mediated upregulation of MMP-3. J Orthop Res 32: 1701-1707.

Mavrogonatou E, Eliades T, Eliades G, Kletsas D (2010) The effect of triethylene glycol dimethacrylate on p53-dependent G2 arrest in human gingival fibroblasts. Biomaterials 31: 8530-8538.

Mavrogonatou E, Kletsas D (2009) High osmolality activates the $\mathrm{G} 1$ and $\mathrm{G} 2$ cell cycle checkpoints and affects the DNA integrity of nucleus pulposus intervertebral disc cells triggering an enhanced DNA repair response. DNA Repair (Amst) 8: 930-943.

Mavrogonatou E, Kletsas D (2010) Effect of varying osmotic conditions on the response of bovine nucleus pulposus cells to growth factors and the activation of the ERK and Akt pathways. J Orthop Res 28: 1276-1282. 
Mavrogonatou E, Kletsas D (2012) Differential response of nucleus pulposus intervertebral disc cells to high salt, sorbitol, and urea. J Cell Physiol 227: 1179-1187.

Nasto LA, Robinson AR, Ngo K, Clauson CL, Dong Q, St Croix C, Sowa G, Pola E, Robbins PD, Kang J, Niedernhofer LJ, Wipf P, Vo NV (2013) Mitochondrialderived reactive oxygen species (ROS) play a causal role in aging-related intervertebral disc degeneration. J Orthop Res 31: 1150-1157.

Nerlich AG, Bachmeier BE, Schleicher E, Rohrbach H, Paesold G, Boos N (2007) Immunomorphological analysis of RAGE receptor expression and NF-kappaB activation in tissue samples from normal and degenerated intervertebral discs of various ages. Ann N Y Acad Sci 1096: 239-248.

Nerlich AG, Schleicher ED, Boos N (1997) 1997 Volvo Award winner in basic science studies. Immunohistologic markers for age-related changes of human lumbar intervertebral discs. Spine (Phila Pa 1976) 22: 2781-2795.

Owuor ED, Kong AN (2002) Antioxidants and oxidants regulated signal transduction pathways. Biochem Pharmacol 64: 765-770.

Papadopoulou A, Kletsas D (2011) Human lung fibroblasts prematurely senescent after exposure to ionizing radiation enhance the growth of malignant lung epithelial cells in vitro and in vivo. Int J Oncol 39: 989-999.

Park JY, Kang KA, Kim KC, Cha JW, Kim EH, Hyun JW (2013) Morin Induces Heme Oxygenase-1 via ERKNrf2 Signaling Pathway. J Cancer Prev 18: 249-256.

Park WH (2013) $\mathrm{H}_{2} \mathrm{O}_{2}$ inhibits the growth of human pulmonary fibroblast cells by inducing cell death, GSH depletion and G1 phase arrest. Mol Med Rep 7: 1235-1240.

Passos JF, von Zglinicki T (2006) Oxygen free radicals in cell senescence: are they signal transducers? Free Radic Res 40: 1277-1283.

Pedruzzi LM, Stockler-Pinto MB, Leite M, Jr., Mafra D (2012) Nrf2-keap1 system versus NF-kappaB: the good and the evil in chronic kidney disease? Biochimie 94: 2461-2466.

Pockert AJ, Richardson SM, Le Maitre CL, Lyon M, Deakin JA, Buttle DJ, Freemont AJ, Hoyland JA (2009) Modified expression of the ADAMTS enzymes and tissue inhibitor of metalloproteinases 3 during human intervertebral disc degeneration. Arthritis Rheum 60: 482491.

Pratsinis H, Constantinou V, Pavlakis K, Sapkas G, Kletsas D (2012) Exogenous and autocrine growth factors stimulate human intervertebral disc cell proliferation via the ERK and Akt pathways. J Orthop Res 30: 958-964.

Pratsinis H, Kletsas D (2007) PDGF, bFGF and IGF-I stimulate the proliferation of intervertebral disc cells in vitro via the activation of the ERK and Akt signaling pathways. Eur Spine J 16: 1858-1866.

Roberts S, Caterson B, Menage J, Evans EH, Jaffray DC, Eisenstein SM (2000) Matrix metalloproteinases and aggrecanase: their role in disorders of the human intervertebral disc. Spine (Phila Pa 1976) 25: 3005-3013.

Roberts S, Evans EH, Kletsas D, Jaffray DC, Eisenstein SM (2006a) Senescence in human intervertebral discs. Eur Spine J 15 Suppl 3: S312-316.
Roberts S, Evans H, Trivedi J, Menage J (2006b) Histology and pathology of the human intervertebral disc. J Bone Joint Surg Am 88 Suppl 2: 10-14.

Roninson IB (2002) Tumor senescence as a determinant of drug response in vivo. Drug Resist Updat 5: 204-208.

Serrano M, Lin AW, McCurrach ME, Beach D, Lowe SW (1997) Oncogenic ras provokes premature cell senescence associated with accumulation of p53 and p16INK4a. Cell 88: 593-602.

Singh K, Masuda K, Thonar EJ, An HS, Cs-Szabo G (2009) Age-related changes in the extracellular matrix of nucleus pulposus and anulus fibrosus of human intervertebral disc. Spine (Phila Pa 1976) 34: 10-16.

Sivan SS, Hayes AJ, Wachtel E, Caterson B, Merkher Y, Maroudas A, Brown S, Roberts S (2014) Biochemical composition and turnover of the extracellular matrix of the normal and degenerate intervertebral disc. Eur Spine J 23 Suppl 3: S344-353.

Sivan SS, Tsitron E, Wachtel E, Roughley P, Sakkee N, van der Ham F, Degroot J, Maroudas A (2006) Age-related accumulation of pentosidine in aggrecan and collagen from normal and degenerate human intervertebral discs. Biochem J 399: 29-35.

Studer RK, Gilbertson LG, Georgescu H, Sowa G, Vo N, Kang JD (2008) p38 MAPK inhibition modulates rabbit nucleus pulposus cell response to IL-1. J Orthop Res 26: 991-998.

Sykiotis GP, Habeos IG, Samuelson AV, Bohmann D (2011) The role of the antioxidant and longevity-promoting Nrf2 pathway in metabolic regulation. Curr Opin Clin Nutr Metab Care 14: 41-48.

Toussaint O, Medrano EE, von Zglinicki T (2000) Cellular and molecular mechanisms of stress-induced premature senescence (SIPS) of human diploid fibroblasts and melanocytes. Exp Gerontol 35: 927-945.

Urban JP, Roberts S (2003) Degeneration of the intervertebral disc. Arthritis Res Ther 5: 120-130.

Urban JP, Smith S, Fairbank JC (2004) Nutrition of the intervertebral disc. Spine (Phila Pa 1976) 29: 2700-2709.

Vo N, Niedernhofer LJ, Nasto LA, Jacobs L, Robbins PD, Kang J, Evans CH (2013) An overview of underlying causes and animal models for the study of age-related degenerative disorders of the spine and synovial joints. $\mathrm{J}$ Orthop Res 31: 831-837.

von Zglinicki T, Pilger R, Sitte N (2000) Accumulation of single-strand breaks is the major cause of telomere shortening in human fibroblasts. Free Radic Biol Med 28: 64-74.

Wu ZH, Shi Y, Tibbetts RS, Miyamoto S (2006) Molecular linkage between the kinase ATM and NFkappaB signaling in response to genotoxic stimuli. Science 311: 1141-1146.

Wuertz K, Vo N, Kletsas D, Boos N (2012) Inflammatory and catabolic signalling in intervertebral discs: the roles of NF-kappaB and MAP kinases. Eur Cell Mater 23: 103-120.

Zdanov S, Toussaint O, Debacq-Chainiaux F (2009) p53 and ATF-2 partly mediate the overexpression of COX-2 in $\mathrm{H}_{2} \mathrm{O}_{2}$-induced premature senescence of human fibroblasts. Biogerontology 10: 291-298. 


\section{Discussion with Reviewers}

Reviewer I: Does the NP cell senescence model induced by $\mathrm{H}_{2} \mathrm{O}_{2}$ treatment correspond to the situation in degenerated intervertebral disc?

Authors: It is known that the intervertebral disc offers a harsh environment to its containing cells due to the peculiar physicochemical conditions prevailing in this tissue (high osmolality as a result of the extracellular matrix composition and the mechanical forces the tissue is subjected to, low oxygen concentration and limited nutrients' availability due to the absence of vascularisation, low $\mathrm{pH}$ due to the almost compulsory anaerobic metabolism of the cells and oxidative stress provoked by the accumulation of catabolic by-products).

The presence of senescent cells in degenerated intervertebral discs has been reported (Freemont, 2009; Gruber et al., 2007; Le Maitre et al., 2007a; Roberts et al., 2006a), thus the induction of senescence in an in vitro nucleus pulposus cell culture could correspond to the situation of the degenerated disc. However, we believe that senescent phenotype in vivo is the combined result of all stressful conditions the cells are exposed to and not of an individual factor, such as reactive oxygen species. In this respect, $\mathrm{H}_{2} \mathrm{O}_{2}$ was used in our experiments just as a physiologically relevant means to trigger senescence, since this oxidative agent has been shown to exist in the tissue in vivo (Kim et al., 2009).

Reviewer II: How does the simulation of oxidative stress by hydrogen peroxide application correspond to oxidative stress in the nucleus pulposus of intervertebral discs? Does the applied protocol simulate physiological levels for normal or degenerated discs? Would the authors expect different results with cells of the annulus fibrosus?

Authors: The existence of oxidative stress in the intervertebral disc in vivo has been established by the accumulation of carboxymethyl-lysine in the proteins especially of the nucleus pulposus. In addition, the presence of $\mathrm{H}_{2} \mathrm{O}_{2}$ in human nucleus pulposus specimens has been demonstrated (Kim et al., 2009), allowing us to assume that nucleus pulposus cells are confronted with this particular oxidative agent in vivo. The $\mathrm{H}_{2} \mathrm{O}_{2}$ content in human nucleus pulposus specimens has been found to be around $0.25 \mu \mathrm{mol}$ per $20 \mathrm{mg}$ of tissue with no differences among different degeneration grades (Kim et al., 2009). $\mathrm{H}_{2} \mathrm{O}_{2}$ is also produced by chondrocytes in vitro (Tiku et al., 1990). In consideration of these previously reported data on nucleus pulposus cells and specimens, we selected to perform our experiments in nucleus pulposus cells. We believe that our in vitro model could simulate one aspect of senescence in the degenerated disc (among a variety of factors that may in combination contribute to the appearance of senescent cells in vivo), since we demonstrated that $\mathrm{H}_{2} \mathrm{O}_{2}$-senescent nucleus pulposus cells are characterised by a catabolic gene expression profile typical of the aged or degenerated disc. Based on our experience with intervertebral disc cells in our laboratory and taking into account their similar responses towards a number of physiological insults, we would not expect a different behaviour of annulus fibrosus cells from that of nucleus pulposus cells after exposure to $\mathrm{H}_{2} \mathrm{O}_{2}$.

Reviewer III: These results were measured with cells in monolayer culture and normoxia. Monolayer is a very unnatural state for these cells. Do the authors have any evidence that the exposure with $\mathrm{H}_{2} \mathrm{O}_{2}$ would be possible in $3 \mathrm{D}$ alginate bead culture or pellet culture and these effects could be even more enhanced, for instance under hypoxia? Authors: We share the Reviewer's opinion that 3D cultures can better simulate the in vivo conditions of nucleus pulposus cells in the tissue. In fact, there is an ongoing research in our laboratory on the responses of these cells towards various physiological conditions using $3 \mathrm{D}$ cultures in alginate beads. Our preliminary unpublished results indicate a similar behaviour of the cells exposed to $\mathrm{H}_{2} \mathrm{O}_{2}$ under normoxic and hypoxic conditions when cultured in monolayers, while many similarities seem to exist between $2 \mathrm{D}$ and $3 \mathrm{D}$ alginate bead cultures in a hypoxic environment.

Reviewer IIII: In this study, human IVD cells from degenerated tissue were used. How might the results change if healthy human IVD cells or bovine IVD cells were used and why?

Authors: We share the Reviewer's concern about possible different behaviours of IVD cells deriving from a healthy/ degenerated tissue or from different species. However, we strongly believe that the general cellular responses towards oxidative stress observed in this study would be similar if we had used healthy human or bovine IVD cells. What we could expect to be different would probably be the range of cytotoxic $\mathrm{H}_{2} \mathrm{O}_{2}$ concentrations. We feel, for example, that bovine IVD cells (which - based on our laboratory experience - exhibit a much higher proliferation rate than human pathologic IVD cells) may have been more sensitive to $\mathrm{H}_{2} \mathrm{O}_{2}$ treatment. Otherwise, we would expect activation of the same biochemical pathways.

Editor's Note: Scientific Editor in charge of the paper: Mauro Alini. 